\title{
Should Lucas v. South Carolina Coastal Council Protect Where the Wild Things Are? Of Beavers, Bob-o-Links, and Other Things that Go Bump in the Night
}

Hope M. Babcock

Georgetown University Law Center, babcock@law.georgetown.edu

This paper can be downloaded free of charge from:

https://scholarship.law.georgetown.edu/facpub/958

85 lowa L. Rev. 849-905 (2000)

This open-access article is brought to you by the Georgetown Law Library. Posted with permission of the author. Follow this and additional works at: https://scholarship.law.georgetown.edu/facpub

Part of the Constitutional Law Commons, Environmental Law Commons, Land Use Law Commons, and the Property Law and Real Estate Commons 


\section{Should Lucas v. South Carolina Coastal Council Protect Where the Wild Things Are?: Of Beavers, Bob-o-Links, and Other Things that Go Bump in the Night}

Hope M. Babcock

I. INTRODUCTION 850

II. HOW WILDLIFE LAWS INTERFERE WTTH THE ABSOLUTE DOMINION EXPECTATIONS OF MODERN LANDOWNERS

III. INHERITED NOTIONS OF PRIVATE LAND OWNERSHIP AND ITS REGULATION AT THE FOUNDING.

A. LAND OWNERSHIP IN COLONIALAMERICA ….............................8 862

B. ENCUMBERED OWNERSHIP RIGHTS .........................................8 871

C. EARLY AMERICANATTITUDES TOWARD WILD LANDS..................877

IV. EARLY AMERICAN COMMON LAW DOCTRINES AFFECTING WILDLIFE AND WILDLIFE HABITAT

A. THE STATE WILDLIFE TRUST DOCTRINE ................................ 883

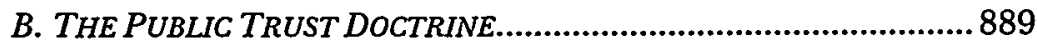

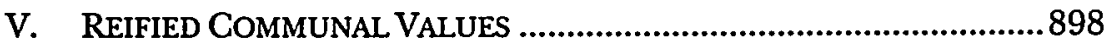

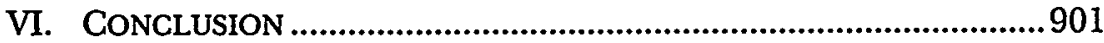

1. MAURICE SENDAK, WHERE THE WILD ThINGS ARE (25th Anniversary ed. 1988).

*Professor of Law, Georgetown University Law Center. With thanks to Professors Dan Ernst, Richard Lazarus, and John Echeverria for their helpful comments on earlier drafts of this Article; to Constance Rogers (GULC ' 00 ) and Kristina Hellman (GULC '00) for their invaluable assistance; and to Georgetown University Law Center for giving me a Summer Writing grant, under the auspices of which I wrote this Article. An earlier, much-abbreviated version of this Article was presented at a conference on "Litigating Regulatory Takings Claims," cosponsored by the Environmental Policy Project and Georgetown University Law Center Continuing Legal Education Program (San Francisco, Cal., Sept. 24-25, 1998). 
There is nothing which so generally strikes the imagination, and engages the affections of mankind, as the right of property, or that sole and despotic dominion which one man claims and exercises over the external things of the world, in total exclusion of the right of any other individual in the universe. ${ }^{2}$

Whenever protection is accorded [to wildlife] harm may be done to the individual. Deer or moose may browse on his crops; mink or skunks kill his chickens; robins eat his cherries. In certain cases the Legislature may be mistaken in its belief that more good than harm is occasioned. But this is clearly a matter which is confined to its discretion. It exercises a governmental function for the benefit of the public at large and no one can complain of the incidental injuries that may result. ${ }^{3}$

\section{INTRODUCTION}

Lucas v. South Carolina Coastal Council ${ }^{4}$ is one of several recent Supreme Court decisions in which the Court used the Just Compensation Clause $^{5}$ as a "weapon of reaction" 6 to strike down an offending land use restriction. ${ }^{7}$ In Lucas, the target of the Court's animus was a state law prohibiting a landowner from developing two beachfront lots. ${ }^{8}$ The South Carolina Supreme Court upheld the law as a legitimate exercise of the State's police power to protect the public from harm in the face of a takings challenge by the landowner. ${ }^{9}$ The U.S. Supreme Court rejected the South Carolina court's talismatic reliance on police power authority. Instead, the Court focused its attention on the fact that the application of the state law

2. 2 WILLIAM BLACKSTONE, COMMENTARIES *2.

3. Barrett v. State, 116 N.E. 99, 100 (N.Y. 1917).

4. 505 U.S. 1003 (1992).

5. U.S. CoNST. amend. V. The Just Compensation Clause states "[N]or shall private property be taken for public use without just compensation." Id.

6. J. Peter Byrne, Greening Property, 7 Consr. CommentaRy 239, 245 (1990).

7. See Dolan v. City of Tigard, 512 U.S. 374, 394 (1994) (finding takings effected by physical exaction that did not demonstrate rough proportionality between permit requirement and avoided harm); Nollan v. California Coastal Comm'n, 483 U.S. 825, 832 (1987) (finding public-access easement attached to a building permit worked a taking because of inadequate nexus between harm state sought to prevent and means chosen to prevent the harm); First English Evangelical Lutheran Church v. County of Los Angeles, 482 U.S. 304, 307 (1987) (finding county ordinance prohibiting building in a flood plain effected a taking even when ordinance was later rescinded); see also City of Monterey v. Del Monte Dunes at Monterey Ltd., 526 U.S. 687 (1999) (holding that submitting to a jury the factual questions of whether the landowner was deprived of all economically viable use of the property and whether Monterey's decision to reject a development plan bore a reasonable relationship to its proffered justifications, and holding that such a submission did not create a rule of takings law that allowed too much interference by the judicial system into municipal land use lavs, policies, and regulations).

8. Lucas, 505 U.S. at 1007-09.

9. Lucas v. South Carolina Coastal Council, 404 S.E.2d 895, 902 (S.C. 1991). 
deprived this particular landowner of all economically beneficial use of his property, and put forward a new "bright line" rule to guide lower courts in such situations ${ }^{10}$ - that compensation will be required whenever a regulation has the effect of economically confiscating private property. ${ }^{11}$ But, the rule that emerged from Lucas is anything but "bright," because the majority included an exception for limitations that "inhere in the title itself, in the restrictions that background principles of the State's law of property and nuisance already place on land ownership." 12 The apparent rationale behind the excep-

10. Lucas, 505 U.S. at 1014-19. Until Lucas, per se takings only existed in the instance of government-authorized physical invasion (or occupation) of private property. See Loretto v. Teleprompter Manhattan CATV Corp., 453 U.S. 419 (1982) (holding that a governmentauthorized, permanent physical invasion of property is automatically a taking, regardless of the magnitude of the interference against the property owner, or the import of the governmental interest).

11. On the issue of compensating landowners for the dimunition in property value, see Daphna Lewinsohn-Zamir, Compensation for Injuries to Land Caused by Planning Authorities: Towards a Comprehensive Theory, 46 U. TORONTO L.J. 47, 53-60 (1996) (arguing that not every restriction on the use of land (e.g., limitations due to physical and economic constraints on land development) generates a complementary obligation to reimburse the owner). Lewinsohn-Zamir suggests that compensation may be inappropriate depending on the magnitude of the impact of the constraint and the extent of its distribution and directness, the costs of awarding compensation, whether the restriction prevents harmful activity by the landowner, there are non-monetary benefits, or whether compensation would be inappropriate on certain moral grounds or defeat some policy goals. $I d$. at 49 . Still, other scholars argue that no compensation is required because the risk of decreased property value from regulatory constraints is internalized in the market price of the affected land, rendering compensation unnecessary because no harm has occurred. See Frank I. Michelman, Property, Utility and Fairness: Comments on the Ethical Foundation of "Just Compensation" Law, 80 HARV. L REV. 1165, 1238 (1967) [hereinafter Property, Utility and Fairness] (arguing that the expectation of possible regulation decreases market price); Margaret J. Radin, Property and Personhood, 34 STAN. L. REv. 957, 1008 (1982) (advocating Michelman's theory).

12. Lucas, 505 U.S. 1003,1029 (emphasis added). The concept that there are preexisting limitations on a landowner's use of her property that immunize the government from a takings claim when it acts in furtherance of those restrictions is far from novel. See Otis v. Ludlow Mfg. Co., 201 U.S. 140, 154 (1908) (writing for the majority, Chief Justice Holmes noted that "[e]ven the incidents of ownership may be cut down by the peculiar laws and usages of a State"). In Otis, the Court affirmed the constitutionality of a state Mill Act which authorized the flooding of upstream property by downstream landowners so long as compensation was paid to the upstream landowner, because of the "long settled law and common understandings" in Massachusetts. Id.; see Board of Regents v. Roth, 408 U.S. 564, 567 (1972) ("Property interests, of course are not created by the Constitution. Rather, they are created and their dimensions are defined by existing rules or understandings that stem from an independent source such as state law ...."); Scranton v. Wheeler, 179 U.S. 141, 162 (1900) (holding that riparian rights are subject to an implied reservation by the government to regulate or make improvements in the public interest); Eldridge v. Trezevant, 160 U.S. 452 (1896) (rejecting a Fourteenth Amendment challenge to the construction of a levee to control a river on the plaintiffs property because a Louisiana state law created a public servitude on private lands abutting rivers and bayous); Michael A. Heller, The Boundaries of Private Property, 108 YALE L.J. 1163, 1190 
tion is that such laws do no more than could have been achieved by courts applying common law principles. ${ }^{13}$ However, the exact meaning of the italicized phrase, and hence its effect, is far from clear, and the phrase has drawn the attention of many commentators. ${ }^{14}$ It is the focus of this Article as well. ${ }^{15}$

(1999) ("[The] Court relies primarily on state law and background conceptions, which in turn incorporate shifting property metaphors.").

13. Since the use of that property "for what are now expressly prohibited purposes was always unlawful, and (subject to other constitutional limitations), it was open to the State at any point to make the implication of these background principles of nuisance and property law explicit." Lucas, 505 U.S. at 1030.

14. See, e.g., Richard C. Ausness, Regulatory Takings and Wetland Protection in the Post-Lucas Era, 30 LAND \& WATER L. REv. 349, 350, 387-90 (1995) (discussing the Lucas opinion); William W. Fisher III, The Trouble With Lucas, 45 STAN. L. REv. 1393, 1397-1402 (1993) (discussing the theoretical foundations of Scalia's opinion); John A. Humbach, Evclving Thresholds of Nuisance and the Takings Clause, 18 COLUM. J. ENVTL. L. 1, 1-4 (1993) [hereinafter Humbach, Evolving Thresholds] (arguing that the common law will now preempt remedial statutes and that Lucas transferred land use control decisions from the legislature to the judiciary); John A. Humbach, "Taking" the Imperial Judiciary Seriously: Segmenting Property Interests and Judicial Revision of Legislative Judgments, 42 CATH. U. L. REV. 771, 772 (1993) (arguing that the Lucas exception reassigned land use control from the legislature to the judiciary); Richard J. Lazarus, Putting the Correct "Spin" on Lucas, 45 STAN. L. REv. 1411, 1419 (1S93) (stating that while the Lucas opinion seemed favorable to property rights advocates, the exception actually rejected much, if not all of Lucas's legal theory); Joseph L. Sax, Property Rights and the Economy of Nature: Understanding Lucas v. South Carolina Coastal Council, 45 STAN. L. REv. 1433, 1438 (1993) [hereinafter Sax, Property Rights] (stating that Lucas is consistent with the Court's restraint in other takings cases and provides states with wide latitude in determining the extent to which their legal principles limit property rights); Glenn P. Sugameli, Takings Issues in Light of Lucas v. South Carolina Coastal Council: A Decision Full of Sound and Fury Signifynig Nothing, 12 VA. ENVTL. L.J. 439, 458.68 (1993) (stating that the categorical rule armounced in Lucas was defeated by the exception); Lynn Graham Cook, Comment, Lucas and Endangered Species Proteclions: When "Take" and "Takings" Collide, 27 U.C. DAvis L. REv. 185, 203-04 (1993) (stating that state and federal governments could regulate land use without compensation if the use could be prohibited as a nuisance); see also Hope M. Babcock, Has the U.S. Supreme Court Finally Drained the Sulamp of Takings Jurisprudence?: The Impact of Lucas v. South Carolina Coastal Council on Wetlands and Coastal Barrier Beaches, 19 HARV. L. REv. 1, 3 n.7 (1995) [hereinafter Babcock, The Impact of Lucas] (concluding that Lucas vill not necessarily lead to further destruction of natural resources); Michael C. Blumm, The End of Environmental Law? Libertarian Property, Natural Law, and the Just Compensation Clause in the Federal Circuit, 25 ENVTL. L. 171, $173 \mathrm{n} .21$ (1995) (providing a list of additional articles on Lucas).

15. Courts around the country are beginning to give content to that phrase, although no court has applied the phrase to the subject of this Article, state wildlife laws. See Kim v. City of New York, 681 N.E.2d 312 (N.Y. 1997) (holding New York City's placement of fill on plaintiffs property to support an adjacent city road, though plainly a physical occupation, did not effect a compensable taking because the landowner held his properry subject to the New York common law obligation to provide lateral support for public roadways); see also Coastal Petroleum v. Chiles, 701 So. 2d 619 (Fla. Dist. Ct. App. 1997) (finding that a state law barring oil and gas development along the Florida coast was not a taking because private rights to engage 
This Article suggests that Lucas was primarily an attempt by the Court to simplify the judicial task of resolving what Robert Gordon refers to as the "hard cases" involving land use disputes, ${ }^{16}$ and that, with respect to laws protecting wildlife, the Court did not succeed in its quest. "Hard cases" arise because the Court's approach to land use disputes that arise in a constitutional setting requires judges to arbitrate among reasonable property uses in a regulated commons of relative rights. ${ }^{17}$ By substituting a reflexive, "bright line" rule for "artful harm-preventing characterizations"

in development are limited by public property rights under navigable waters); Public Access Shoreline Haw. v. Hawaii County Planning Comm'n, 903 P.2d 1246 (Haw. 1996) (finding that private rights in real estate held for development purposes were subject to native property rights); Adirondack League Club, Inc. v. Sierra Club, 706 N.E.2d 1192 (N.Y. 1998) (rejecting a claim by landowners that recreational boaters' use of a river violated the adjacent landowners' property rights, based in part on Lucas); Stevens v. City of Cannon Beach, 854 P.2d 449 (Or. 1993), (holding that Oregon's customary public property rights in ocean beaches precluded a takings claim challenging regulations restricting beach development).

16. Robert Gordon, Paradoxical Property, in EARLY MODERN CONCEPTIONS OF PROPERTY 95, 101 (John Brewer \& Susan Staves eds., 1995). In land use disputes, courts become hard pressed to rationalize tradeoffs among utilitarian or other preferred uses in the language of rights, and do this by focusing on the protected user as the absolute right-holder and ignoring the rights of other parties, by redefining the property right as "absolute," but narrowing it considerably by saying that the right extends only to "natural" uses of the property, or by acknowledging the harm to property, but denying that harm constitutes a legally cognizable injury, saying instead that the injury is merely "indirect" or "consequential" damage, demnum absque injuria. Gordon, supra, at 100-01. But, according to Gordon, abandoning the language of rights for that of policy and commerical convenience simply recasts these disputes into a different vocabulary, and does not resolve the hard cases either. Id. at 101.

17. Robert Gordon calls this approach to land use decisions the "relative rights model." Gordon, supra note 16, at 100-01. In Paradoxical Property, he explains how "the rise of industrial noxious uses to abutting landowners, milldam construction that flooded meadows or interfered with watercourses, mining or road building that undercut lateral support to land, manufacturing that polluted neighboring streams or air and frightened off game, and building construction that cut off light" led to the creation of various legal regimens by courts for handling these conflict. Id. Under the dominant regime of eighteenth-century American nuisance law, the first person to appropriate a property right becomes the absolute right-holder against all latecomers. Id. This property right was later converted into a liability rule, which allows the nuisance to continue so long as the landowner pays for damage done to adjacent property. Id. at 100-01. Another approach converts use-rights into privileges without imposing any correlative duty, like compensation for impaired or lost use, on the right-holder; while yet a third approach, which has become the regime preferred by most courts, requires conflicting land owners to limit their respective uses up to the point of conflict with other uses. Id.

18. Prior to Lucas, the Court relied on the "harm/benefit" test (benefit-conferring regulations worked a taking while those intended to prevent a public harm do not) and the "average reciprocity of advantage" rule (regulations that confer reciprocal benefits on the regulated parties do not effect a taking) to adjudicate takings claims. Lynda J. Oswald, The Role of the "Harm-Benefit" and "Average Reciprocity of Advantage" Rules in a Comprehensive Takings Analysis, 50 VAND. L. REV. 1449 (1997). In Lucas, Justice Scalia effectively eliminated the harmpreventing/benefit-conferring test. See Lucas, 505 U.S. at $1025-26$ n.12. (stating that because a 
other highly flexible prudential memes, ${ }^{19}$ like "noxious use" and "average reciprocity of advantage," of Gordon's relative rights box by converting a landowner's relative use right into an unassailable privilege, thereby simplifying the task of the lower courts. ${ }^{21}$ But Lucas may have perversely achieved precisely the opposite result because the Court did not completely eliminate these atavistic doctrinal defenses. Instead, the majority tried to cabin them by anchoring them to common law principles. ${ }^{22}$ However, these principles come from an

harm prevention rationale can be devised for almost every case, "the Takings Clause requires courts to do more than insist upon artful harm-preventing characterizations."). He rejected "noxious-use logic" as a "touchstone" in distinguishing between those regulatory takings that require compensation and those that do not. $I d$. at 1026. For a more thorough discussion of these concepts and an argument in favor of their revival in evaluating the validity of the government's exercise of power, see Oswald, supra at 1481 (1997) (arguing regardless of what you label the "harm/benefit" calculation, it "provides a rough-and-ready analytical tool for resolving most takings questions").

19. A meme is defined as a "unit of cultural transmission which has the property of selfreplication as it propagates from brain to brain-a pattern of information that has evolved to a form which induces people to repeat the pattern." Hope M. Babcock, Democracy's Discontent in a Complex World: Can Avalanches, Sandpiles, and Finches Optimize Michael Sandel's Civic Republican Community?, 85 GEO. LJ. 2085, 2089 n.27 (1997). Examples of memes include slogans, catchphrases, melodies, and jingles. Id.

20. The majority criticized the South Carolina Supreme Court for being "too quick" to decide the case based on the power of government to proscribe harmful or noxious uses of property without compensation. Lucas, 505 U.S. at 1022; see Lewinsohn-Zamir, supra note 11, at 76-83 (criticizing the sweeping use of harm-prevention, because it leads to over-restriction of activities without providing compensation in return, despite the fact that not every harmful activity is a preventable nuisance (only significant ones), and many of the activities covered have only an insignificant negative effect on their surroundings).

21. See Lucas, 505 U.S. at 1025 (criticizing the relativism of the nuisance exception by saying, "[w]hether one or the other of the competing characterizations will come to one's lips in a particular case depends primarily upon one's evaluation of the worth of competing uses of real estate").

22. Some commentators are highly critical of the Court's inclusion of common law principles in the regulatory takings formula. They fear that the inclusion introduces an even higher amount of indeterminacy and autocracy into what should properly be a matter for democratically elected state legislators. See, e.g., J. Peter Byrne, Ten Arguments for the Abolition of the Regulatory Takings Doctrine, 22 ECOLOGY LQ. 89, 113 (1995) (" $[$ Lucas] reverses the majoritarian premise of every state's constitution, namely, that legislation supersedes common law rules."); William W. Fisher III, The Trouble urith Lucas, 45 STAN. L. REV. 1393, 1407 (1993) ("[W] hat is most striking about the holding of Lucas is that it embeds in the already muddy law of takings . . . the even muddier law of nuisance"); Blaine I. Green, The Endangered Species Act and Fifth Amendment Takings: The Constitutional Limits of Species Protection, 15 YALE J. ON REG. 329, 348-49 (1998) ("By adopting a historically confined definition of nuisance, Lucas effectively limits the nuisance exception to harms that would have been actionable at common law") (footnote omitted); Humbach, Evolving Thresholds, supra note 14, at 3 (criticizing Lucas "for reassign[ing] a significant piece of the nation's ultimate land-use authority from elected state legislatures to the judiciary."). But see Richard A. Epstein, Takings, Exclusivity and Speech: The 
era when property rights were anything but absolute, and remain frozen in that earlier time, when a pig in a parlor was a nuisance ${ }^{23}$ and property ownership included responsibilities to the larger community. ${ }^{24}$ These principles tell a very different story and potentially justify a wide array of land use restrictions, including those protective of wildlife.

The Court's reliance on common law principles to craft an exception to its per se compensation rule misapprehended the continued robustness of old maxims, such as those restricting the uses to which private property can be put when they threaten wildlife, and thus potentially created an exception much wider than intended. Far from simplifying the takings catechism, the resultant misalignment of these principles with landowners' current, albeit misguided, "understandings" ${ }^{25}$ of the State's power over the

Legacy of PruneYard v. Robins, 64 U. CHI. L. REV. 21, 23 (1997) (decrying the unmooring of takings jurisprudence from any common law conceptions of property rights, including nuisance). Torres makes a separate point about the value of indeterminacy in his critique of property rights advocates when he comments favorably on the language in Holmes' opinion, in Pennsyluania Coal Co. v. Mahon, 260 U.S. 393, 415 (1922) (quoting Holmes in Hudson Water Co. v. McCarter, 209 U.S. 349, 355 (1908), where he said "the neighborhood of principles of policy which are other than those on which the particular right is founded, and which becomes strong enough to hold their own when a certain point is reached"). Gerald Torres, Taking and Giving: Police Power, Public Value, and Private Right, 26 ENVT'L L. 1, 23-24 (1996). He applauds Holmes' statement because it correctly describes an evolutionary system for making policy. Id. According to Torres, Holmes displays an "approach to the problems of the extent of governmental regulatory power [that] reveals the constellation of rights, powers, liabilities, and immunities as a dynamic system, not as the mere ordinal ranking of predetermined claims. Id. at 24. That such a dynamic approach to analysis and adjudication leaves much undecided is not a demerit but is, rather, an important value.

23. See Euclid v. Ambler, 272 U.S. 365 (1926) (upholding zoning regulations that prohibited industrial use of land in a residential area of the city); see also Susquehanna Fertilizer Co. v. Malone, 20 A. 900, 902 (Md. 1890) ("The neighbor is entitled to the reasonable and comfortable enjoyment of his property, and, if his rights in this respect are invaded, he is entitled to the protection of the law, let the consequences be what they may."). Houck argues that the majority in Lucas sought to freeze the nuisance exception in the most ancient and established "background principles, which contradicts the very nature of nuisance which makes what used to be acceptable, unacceptable as the lingering pig sty in today's city." Oliver A. Houck, Why Do We Protect Endangered Species, and What Does That Say About Whether Restrictions on Privale Property to Protect Them Constitute "Takings"?, 80 IOWA L. REV. 297, 330 (1995); see infra text accompanying notes 216-220 (discussing Professor Freyfogle's work on public nuisance).

24. See William J. Novak, People's Welfare: LaW and Regulation in Nineteenth CENTURY AMERICA 51-82 (1996) ("The sic utere tuo rationale of nuisance was a public ordering principle of 'every civilized community'").

25. Those "understandings" have led many Americans to believe (wrongly) that they have an absolute right to use their property however they wish. Theoreticians have ascribed important roles and qualities to the institution of property. Lewinsohn-Zamir cites as examples of this Locke's labor theory, which views property rights as natural rights; Hegel's personhood theory, which emphasizes private property as a means for developing personality; and Posner's justification of private property as an important tool for maximizing wealth in society. 
"bundle of rights"26 acquired with the title to property, reveals that the $L u$ cas Court made a major error. This error will result in the continuation of the muddle of the relative rights model, with all of the attendant difficulties of reconciling relational rights with absolute ownership norms, the very "muddle" of takings jurisprudence, ${ }^{27}$ this Article postulates, that the Court sought to undo in Lucas. The error all but guarantees continued conflict and confusion over the extent of those rights whenever restrictive laws are applied..$^{28}$ All is not lost, however, because by making common law understandings of land ownership part of the baseline of any post-Lucas takings analysis, the Court may have inadvertently created a golden opportunity for a return to a more neighborly society and a more ecologically sensitive land use ethic, in which conflicts over the uses of private property disappear.

The Article uses the example of wildlife laws in which to develop these disparate thoughts. Part II briefly discusses the effect of wildlife protection regulations on private land use, and the equity issues raised by their idiosyncratic application. Part III shows how English understandings about the rights and duties of landowners influenced colonial expectations about similar matters at the time of the founding of this country. These understandings are quite different from the ones we have today about property

Lewinsohn-Zamir, supra note 11, at 50-52. Lewinsohn-Zamir goes on to show that although each of these theories justifies some compensation for injury to private property, none grants absolute protection to property rights. Id.; see also O.W. Holmes, The Path of the Law, 10 HARV. L. REv. 457, 476-77 (1897) (justifying the doctrine of prescription by saying that "[t]he true explanation of title by prescription seems to me to be that man, like a tree in the cleft of a rock, gradually shapes his roots to his surroundings, and when the roots have grown to a certain size, can't be displaced without cutting at his life"), quoted in Jeffrey E. Stake, The Uneasy Case for Adverse Possession 32 (1999) (unpublished manuscript, on file with author).

26. This "bundle" is said to consist of a number of different rights: the right to possess the object, the right to use it, the right to exclude others from possession or use, and the right to transfer it. This last right has two aspects, the right to sell and the right to make a gift. See JeSSE DUKeminier \& JAMES KRIER, PROPERTY 86 (3d ed. 1993) (defining the "bundle" of property rights).

27. Carol Rose, Mahon Reconstructed: Why the Takings Issue Is Still a Muddle, 57 S. CAL. L. REV. 562 (1984). Rose is not alone in finding a certain incoherence to the Court's takings jurisprudence. See BRUCE A ACKERMAN, PRIVATE PROPERTY AND THE CONSTITUTION 8 (1977) (illustrating the phrase "chaos of confused argument"); A. L. Peterson, The Takings Clause: In Search of Underlying Principles, Part I - A Critique of Current Talings Clause Doctrine, 77 CAL. L. REv. 1299, 1304 (1989) ("[I]t is difficult to image a body of case law in greater doctrinal and conceptual disarray."); Joseph L. Sax, Takings and the Police Power, 74 YALE L.J. 36, 37 (1964) (illustrating the phrase "a welter of confusing and apparently incompatible results"), quoted in Lewinsohn-Zamir, supra note 11 , at 47.

28. Lucas, 505 U.S. at 1027. Heller points out that the Court's adoption of the "bundle of rights" metaphor is of much more recent vintage than the excerpt implies, and that the adoption came just at the point that the metaphor was losing its place in property theory. Heller, supra note 12, at 1193. 
ownership and reveal a legal convention substantially encumbered by communal obligations, including the obligation to protect wildlife. While Locke's view of private property as a pantheon of important political liberty rights played a formative role in the early rhetoric of this country, it did not reflect or disturb long-held understandings about the conditional and communally restricted nature of rights in property. It is the encumbered, non-Lockean view of property that undergirds the background principles of most states' common law. Part III additionally shows how early colonial law also harbored a deep-seated hostility toward wilderness and explains how some English property doctrines were changed in this country to facilitate cultivation of wild (or "waste") lands, the very lands that are prized today as wildlife habitat.

Part IV of the Article traces the common law roots of our modern wildlife laws and shows how the common law doctrines of state wildlife trust and public trust have protected wildlife in this country because of their importance as communal resources. But this review of the historical antecedents of various common law doctrines and their present day application reveals a legacy at odds with the obvious intent of the majority in Lucas to fashion a narrow exception to the Court's per se compensation rule and with the exclusive, absolute dominion expectations of most modern landowners. Part V of the Article takes a slightly more theoretical look at the communal values underpinning the doctrines described in Part IV by examining the writings of several property scholars who fear that modern "property rights talk" may suppress these more propitious norms. The Article concludes that the Lucas exception may allow wildlife to slip through the Court's takings net. But, unless modern expectations about the correlative rights and obligations of property ownership are aligned more closely with the communal values reflected in the background principles of common law discussed in Part V, the legacy of Lucas will be continued conflict between the individualistic aspirations of private landowners and the more commonweal goals of government regulators, and a golden opportunity to effectuate a more civil society created by the Court's exception will have been lost.

\section{HOW WILDLIFE LAWS INTERFERE WITH THE ABSOLUTE DOMINION EXPECTATIONS OF MODERN LANDOWNERS}

Almost ninety percent of the nearly 1000 species of federally protected plants and animals are found on private land, ${ }^{29}$ and private property con-

29. Gardner M. Brown, Jr. \& Jason F. Shogren, Economics of the Endangered Species Act, 12 J. ECON. PERSP. 3 (Summer 1998). Forty-three percent of these species are dependent on federal-and state-protected wetlands for some portion of their life cycle. See NAT'L WILDLIFE 
tributes substantially to the wildlife habitat resource base. ${ }^{30}$ Laws protecting wildlife challenge the notion of unrestricted dominion over private property, ${ }^{31}$ in some cases substantially restricting the extent to which a landowner can modify her property and thus alter the natural landscape. The prescriptive nature of these laws, ${ }^{32}$ and the broad, often indeterminate,

FED'N, ENDANGERED SPECIES, ENDANGERED WETLANDS: LIFE ON THE EDGE 7 (1992) (providing statistics on the number of threatened species which are wetland dependent); see also Houck, supra note 23, at 319 (citing DEFENDERS OF WILDLIFE, Foreword to BUILDING ECONOMIC INCENTIVES INTO THE ENDANGERED SPECIES ACT vii (Wendy E. Hudson ed., 2d ed. 1993) (stating that "[f]ully fifty percent of the 728 species currently listed as threatened or endangered are found exclusively on private lands")).

30. More than half of the species that are protected by the Endangered Species Act (ESA) have at least eighty-one percent of their habitat on private land. DAVID S. WILCOVE ET AL., Rebuilding the Ark: Toward a More Effective Endangered Species ACt for Private LAND 3 (1996) [hereinafter REBUILDING THE ARK]. An analysis of the geographic distribution of endangered species in the United States revealed that they are concentrated in a relatively small proportion of the land mass, lessening the areas of potential conflict with other activities. Unfortunately, the greatest numbers of these species are found in areas experiencing substantial development, such as Hawaii, California, the southeastern coastal states, and southern Appalachia. A.P. Dobson et al., Geographic Distribution of Endangered Species in the United States, 275 SCI. 550 (Jan. 24, 1997). Only three percent of the federally protected species found entirely on private property are improving; the ratio of declining to improving species is nine to one. REBUILDING THE ARK, supra, at 3 . Some examples of species that are threatened with extinction are the San Joaquin Kit fox, the red-cockaded woodpecker, and the Florida panther. The Kit fox has been listed under the ESA since 1967. Of the foxes' remaining habitat, eighty percent is on private land coveted by agriculture and petroleum developers. The population of the red-cockaded woodpecker, also listed in 1973, continues to decline as a result of logging and fire suppression on private lands. The thirty to fifty remaining Florida panthers live in four areas south of Lake Okeechobee, of which fifty-three percent is privately owned. Id. at 18-20.

31. Gordon considers this view of property paradoxical given property's uncontestable roots in authoritarian control, and bemoans the expansion of what he calls "the absolute dominion trope" to every conceivable type of commercial expectancy. Gordon, supra note 16, at 107. But, Gordon warns, this absolutist image will not soon disappear. Id. Labeling "the freedom to contract, the right to a reasonable return on investment in public utility property, the right to management of one's business without interference, [and] the right to advantageous contractual relations" as property "alchemized [them] into 'natural' entitlements protected against even legislative attempts to revise them." Id. Consider also Freyfogle, who finds among the "inaccurate, pernicious myths embedded in the lore of landed property rights ... the idea that property rights somehow began in absolute form and only deviated from that pure form with the advent of modern land-use controls." Eric T. Freyfogle, The Construction of Oumership, 1996 U. ILL. L. REv. 173, 178 (1996) [hereinafter Freyfogle, Ounership].

32. See Tennessee Valley Auth. v. Hill, 437 U.S. 153, 184 (1978) (stopping the construction of an almost completed dam and saying "[t]he plain intent of Congress in enacting [the Endangered Species Act] was to halt and reverse the trend toward species extinction, whatever the cost"). 
dynamic landscape to which they apply, ${ }^{38}$ heighten the opportunity for conflict $^{34}$ with landowners' expectations about the absolute and permanent nature of their rights. The fact that the benefits of protecting wildlife inure to an undifferentiated public ${ }^{35}$ gives cold comfort to the individual land-

33.

The real difficulty is that modern ecological theory has eroded the notion of a bounded domain, often almost to the vanishing point. Many things that a short time ago were thought entirely the business of a landowner within the confines of his or her own land are now revealed to be intimately interconnected with other lands and with public resources that have never been thought to belong to the owner of a given tract.

Joseph L. Sax, The Constitutiomal Dimensions of Property: A Debate, 26 LOY. L.A. L. REv. 23, 33 (1992); see Freyfogle, Ownership, supra note 31, at 175 ("To the overflying hawk, human boundaries mean nothing. To the percolating groundwater, they mean no more."); see generally EDWARD O. WILSON, THE DIVERSTTY OF LIFE (1993) (examining the interdependence within the biosphere). Wilson explains that a sound environmental policy may include the production of biological wealth and sustainable development. Id. at 319-29. Singer and Beerman attribute the same indeterminacy to property rights. Joseph William Singer \& Jack M. Beerman, The Social Origins of Property, 6 CAN. J. L. \& JuRISPRUDENCE 217, 228 (1993) ("Because property is socially and politically constructed, the scope of property rights changes over time as social conditions and relationships change .... Th[e] power to change the scope of property rights is necessary to preserve their social function.") (emphasis in original), quoted in Marc R. Poirier, Property, Environment, Community, 12 J. ENVTL. L. \& LrTIG. 43, 54 (1997). Rose makes the same point with respect to changing regulatory priorities. Carol M. Rose, Takings, Federalism, Norms, 105 YALE L.J. 1121, 1149 (1996) ("[T]akings jurisprudence is not and cannot be aimed simply at fairness to individuals.... [I]t must also be aimed at allowing communities to alter their regulatory practices to confront changing patterns of resource use ...."). See also Torres, who views the interplay between property claims and government power as a "constellation of rights, powers, liabilities, and immunities" in a "dynamic system, not as the mere ordinal ranking of predetermined claims." Torres, supra note 22, at 24; see generally J. B. Ruhl, The Fitness of Law: Using Complexity Theory to Describe the Evolution of Law and Society and Its Practical Meaning for Democracy, 49 VAND. L. REv. 1407 (1996) (using complexity theory to explain how and why the law changes).

34. See Babbitt v. Sweet Home Chapter, 515 U.S. 687 (1995), which, by affirming the application of Section 9 of the Endangered Species Act (ESA), 16 U.S.C. § 1538, prohibiting taking endangered species to include habitat modification, increased the likelihood of conflict with landowners. Although Habitat Conservation Plans (HCPs) were added to the ESA in 1982 to lessen conflict with private landowners, pressure by citizens to make these plans sufficiently rigorous may instead fuel it. For a contrary view of HCPs, see Green, supra note 22, at 376 (asserting that HCPs embody Fifth Amendment guarantees).

35. For example, angler and hunting expenditures in the United States generated around $\$ 60$ billion in 1996. Brown \& Shogren, supra note 29, at 11 (citing U.S. Fish \& Wildlife Service/National Marine Fisheries Service, Making the ESA Work Better: Implementing the 10 Point Plan and Beyond (1997)). Commercial and recreational fishing in the Pacific Northwest helps to support 60,000 jobs and $\$ 1$ billion in personal income in the regional economy. Id. at 12 (citing W.R. Irvin, Statement to the United States Senate Committee on Environmental and Public Works, Subcommittee on Drinking Water, Fisheries, and Wildlife (July 13, 1995)). The rapidly growing ecotourism industry, in which people pay to observe certain species, like the $\$ 200$ million California whale-watching industry, provides another source of economic benefit from 
owner who must bear alone the costs of the restriction on her activities, however unintended or incidental to an otherwise laudable public policy. Stories about federal laws that interfere with property owners' investmentbacked expectations abound ${ }^{36}$ and are used by property rights advocates to attack laws protecting wildlife. They also dramatize (some might say demonize) the impact of government regulations on private landowners, who in turn become "poster children" in campaigns against these laws. ${ }^{37}$

Modern day restrictions on the use of private land that protect wildlife,

species preservation. Id. Approximately fifteen percent of expendirures from a $\$ 90-\$ 200$ billion global ecotourism industry arises from ecotourism in the United States. Id. (citing F. Filion et al., The Economics of Global Ecotourism, in PROTECTED ARIEA ECONOMICS AND POLICY: LINKING CONSERVATION AND SUSTAINABLE DEVELOPMENT (M. Munasinghe \& J. McNeely eds., 1994)); see Dean Lueck, Property Rights and the Economic Logic of Wildlife Institutions, 35 NaT. RESOURCES J. 625, 628 (1995) (illustrating the significant values derived from wildlife in contemporary society to underscore the need to have property institutions designed in such a way as to capture these values).

Many supporters of wildlife laws, however, acknowledge that the benefits flowing from preserving wildlife species, including commercial and consumptive use, will not be sufficient to offset the costs of their preservation. Furthermore, while adding quantified social values to preserving various species would strengthen the preservation side of the economic equation, doing this creates analytical difficulties. Thus, while most economists acknowledge that people may have preferences about protecting species, there is controversy over putting a monetary value on these preferences by using analytical devices such as contingent valuation surveys. See generally Brown \& Shogren, supra note 29, at 12-13 and sources cited therein. Even if the benefit side of the equation can be enhanced, any benefits will still be offset by direct costs (i.e., transaction costs such as time and money spent on applying for permits and licenses) and indirect costs (i.e., the foregone opportunities from restrictions on property use due to wildlife protective measures or reduced economic rents from restricted or altered development projects, wages lost by displaced workers, lower consumer surplus due to higher prices, and lower capital asset value costs of species/habitat protection). Id. at 13. Brown and Shogren cite as an example of such indirect costs those estimated by Bonneville Power Administration with respect to its expenditures in 1994 on salmon conservation. Id. Three hundred million out of a total cost of $\$ 350$ million were the opportunity costs of lost power revenues. $I d$.

36. Even recent efforts to reintroduce endangered species to the wild, which are typically popular with the general public, have triggered intense opposition from nearby landowners because of their fear of eventual government-imposed restrictions on their property. See Holly Doremus, Private Property Interests, Wildlife Restoration, and Competing Visions of a Western Eden, $18 \mathrm{~J}$. LAND, RESOURCES \& ENVTL. L. 41, 45-46 (1998) (claiming that reintroduction efforts create a variety of potential conflicts with private property interests).

37. Green cites the example of a 74-year-old woman who lost the chance to build her retirement home because use of her property would harm the endangered golden-cheeked warbler as a reason why the Endangered Species Act ("ESA") has become an important symbolic target for the property rights movement and for opponents of big government. Green, supra note 22, at 332. According to Green, the Act "dramatizes the impact of federal regulations on individuals, providing anecdotes of property owners whose livelihood is, one way or another, threatened by the government's mandate to save some little-known bird, bug or rodent." Id.; see John D. Echeverria, The Politics of Property Rights, 50 OKLA. L. REv. 351 (1997) (stating that "property rights have become a familiar topic of public debate."). 
such as those found in the federal Endangered Species Act ("ESA") ${ }^{38}$ and state laws, have roots deep in Anglo-American common law. They should be the paradigmatic instance in which the Lucas exception for background principles of common law applies. ${ }^{39}$ But the ostensible lack of synchronicity between these common law precepts and the average property owner's understanding about her rights as a landowner contradicts the notion that there can be commonly held expectations about the extent to which a property owner's title to land may be encrusted with common law rules protective of wildlife. The fact that similarly situated owners may experience different land use restrictions depending on the needs of resident species at the time restrictions are applied raises additional questions of fairness. ${ }^{40}$ The attitudinal ambivalence of the ordinary citizen toward wildlife protection ${ }^{41}$ and a

38. See 16 U.S.C. $\S 1538$ (1994) (prohibiting the taking of any federally protected species of fish or wildlife); Babbitt v. Sweet Home Chapter, 515 U.S. 687 (1995) (affirming that the statutory term "take" includes habitat modification). The application of laws like the ESA to landowners seems, and may in fact be, more dramatic today, perhaps because they are so infrequently and sometimes unexpectedly applied-and when applied they can have an overblown economic impact because wildlife officials have waited until the species' fate has reached crisis proportion before requiring more invasive and draconian protective measures. See, for example, Hal Bernton, Judge Calls Halt to Sales of Timber, PORTLAND Oreconian, Aug. 3, 1999, at Al (discussing a case in which a judge put timber sales on hold because of a violation of the Northwest Forest Plan which endangered the recovery of the Northern Spotted Owl).

39. Given the hostility of property rights advocates toward laws protecting wildlife like the ESA, it is interesting that there has been little litigation testing the constitutionality of these laws. But see Good v. United States, 39 Fed. Cl. 81 (1997), affd 189 F.3d 1355 (Fed. Cir. 1999), cert. denied --S. Ct.--, 2000 WL 339382 (2000) (holding the ESA did not effect a taking where the U.S. Fish \& Wildlife Service recommended reasonable and prudent alternatives pursuant to which some development would have been appropriate). One commentator attributes this strange quiescence, at least with regard to the ESA, to little regulatory activity under the ESA during its early history, uncertainty until recently over whether habitat modification was harm under the Act, efforts by the Fish and Wildlife Service to avoid restrictions on private property use, and the cost of litigation. Green, supra note 22, at 363-67. Supporters of these laws, however, should not be lulled into the false belief that lack of adverse precedent is the same as lack of adverse authority. Id. at 332.

40. Given the unequal effect of land use regulations on similarly situated landowners, and the fact that the impact on landowners is unintentional, failure to compensate would result in unjustified, inefficient, and unfair redistribution of wealth. Lewinsohn-Zamir, supra note 11 , at 53-60.

41. Wildlife is neither well understood nor universally revered by the public. Popular attitudes toward wildlife span the gamut of emotions from pleasure and reliance to annoyance and fear. Michael E. Field, The Evolution of the Wildlife Taking Concept from Its Beginning to Its Culmination in the Endangered Species Act, 21 Hous. L. REv. 457, 459-60 (1984); see Pierson v. Post, 3 Cai. 175, 180 (N.Y. 1805) ("By the pleadings it is admitted that a fox is a "wild and noxious beast.' Both parties have regarded him, as the law of nations does a pirate, 'hostem humani generis,' and although 'de mortuis nil nisi bonum,' be a maxim of our profession, the memory of the deceased has not been spared. His depredations on farmers and on barn yards, have not been forgotten; and to have put him to death wherever found, is allowed to be meri- 
fluid indeterminate regulatory baseline, reflective of our evolving scientific understanding of the needs of various species, ${ }^{42}$ further challenge any preconception that common law rules protecting wildlife inhere in title to land, not withstanding the fact that the common law is brimming with principles reflecting that belief.

\section{INHERITED NOTIONS OF PRIVATE LAND OWNERSHIP AND ITS REGULATION AT THE FOUNDING}

\section{A. LAND OWNERSHIP IN COLONIAL AMERICA}

American colonial law had firm roots in recollected English legal institutions, practices, and values. ${ }^{43}$ English common law provided the legal foundation for property ownership in the colonies, ${ }^{44}$ and, as in England, outright individual ownership of land was not the norm ${ }^{45}$ in the period leading up to the Revolution, nor was the notion of unconditional, permanent title to land. ${ }^{46}$ The idea that the sovereign can restrict uses of private

torious, and of public benefit.") (Livingston, J., dissenting).

42. See infra note $\mathbf{2 2 3}$ (discussing the evolving scientific understanding of species needs).

43. See Bernard J. Hibbitts, Peter Charles Hoffer's Law and People in Colonial America, 12 LAW \& HIST. REv. 197, 198 (Spring 1994) (book review) (commenting that from the very beginning of colonization, English authorities made an effort to ensure substantial continuity between the laws of the colonies and those of the mother country); see also J. W. ELY, THE GUARDIAN OF EVERY OTHER RIGHT: A CONSTITUTIONAL HISTORY OF PROPERTY RIGHTS 10 (1992), quoted in David Schultz, Property Rights in the American Founaing, 37 AM. J. LEG. HIST. 464, 487 (1993) ("The emerging American constitutionalism included respect for the traditional English common law attitudes towards property rights [and those attitudes fit within an ancient constitution that respected the rights of Englishmen].").

44. Instructions to colonial governors explicitly stated that the legal and tenurial rights of colonists were the same as those of residents of the mother country. W. STITT ROBINSON, JR., MOTHER EARTH: LAND GRANTS IN VIRGINIA, 1607-99, at 12 (1957) ("All the lands, tenements, and hereditaments ... shal be had and inherited and enjoyed, according as in the like estates they be had and enjoyed by the lawes within this realme of England.").

45. The word "property" was not applied to the ownership of land in England until the beginning of the seventeenth century, because until then land could be held for services due to a feudal lord and could not be devised by will. Land could sustain multiple, overlapping claims and casual or regular use by many individuals, and was less vulnerable to interference than were goods, animals, or sums of money. David J. Seipp, The Concept of Property in the Early Common Law, 12 L. \& HisT. Rev. 29, 86-87 (1985).

46. Schultz, supra note 43, at 487 (citing L. M. FREIDMAN, A HISTORY OF AMERICAN LAW 51 (1973)). However, Mitchell notes that there were significant differences in attitudes toward property in the New England and southern colonies. JOHN HANSON MTTCHELL, TRESPASSING: AN INQUIRY INTO THE PRIVATE OWNERSHIP OF LAND 119 (1998). The Puritans arrived in New England with a concept of property that included provisions for common as well as individual lots and villages with shared greens or grazing areas that required shared work, decisionmaking and use. This system of overlapping interests in land limited the amount of land speculation that could occur. Id. In the South, land grants were much larger to entice settle- 
property ${ }^{47}$ that are not in the public interest has a solid purchase in English common law, which historically treated property rights as tenuous, ${ }^{48}$ conditional, ${ }^{49}$ and communally bounded. ${ }^{50}$ Land, which could sustain multiple,

ment, which led to and even encouraged speculation. Id. As the English colonists moved west from Virginia, they took with them the southern system. Id. According to Mitchell, the Northwest Ordinance Act, which ordered the surveying of the Western Territories into a system of six-mile square townships to be further subdivided into thirty-six square lots, delivered the coup de grace to wilderness and common spaces with shared responsibilities and use. Id.

The national grid was essentially the ultimate expression of private property, a way of laying out the continent into identifiable, salable lots. . . [Land was] viewed . . not as a place of wilderness and beauty or a source of sustenance, but above all a commodity to be bought and sold primarily for capital gain.

MITCHELL, supra, at 119.

47. For many centuries, the Church had taught that having possessions was not a virtue and might well keep the possessor out of heaven. Property was the "huge boil . . . or hump on the rich man's back that would prevent him from passing through the eye of the needle into heaven." Seipp, supra note 45 , at 70 . Monks who had property in goods were denounced as proprietaries. Id. at 68-70. Thomas More makes the argument in Utopia that property should be exiled and banished. THOMAS MORE, UTOPIA 39-40 (George M. Logan \& Robert M. Adams eds., Cambridge Univ. Press 1975); see Poirier, supra note 33, at $67 \mathrm{n} .91$ (referring to Pope John Paul II, Centesimus Annus (May 2, 1991), in 36 THE POPE SPEAKS 273, 291-97 (1991), as "articulating a conception of property as ultimately limited by the good of the human community as a whole"). Seipp finds that the accounts of medieval lawyers of natural rights in property came out of a rich stream of theological and canonist debates over the moral status of individual property ownership. Seipp, supra note 45, at 87-88. At the same time, there was a creation story that supported the notion of capture creating a possessory interest in wild animals. Id. at 65 . According to that story, in the beginning, all wild animals were obedient to Adam, but when he sinned, they rebelled from his individual control and became "in common, so that a person, who took a wild animal or bird and by industry, labor, and diligence made it tame by restraining its liberty, acquired property in it." Id. By the sixteenth century, the creation story of property, in general, and wild animals, in particular, had taken on a contingent cast, in which commentators stressed the origin of property in human custom (i.e., the rules or laws that said how property was to be allocated), not in the Bible, to indicate how the common law and the King's prerogative could legitimately limit, condition, and divest individual property in goods and animals. By the mid-sixteenth century, this became the dominion over the earth story that is still with us today-that God committed all worldly things to the order and disposal of men, and the apportionment of those things among men was left to be settled by mankind through laws made specifically for that purpose. Id. at 76-77.

48. Individual property in anything could be appropriated by feudal lords, and later, by the King. Seipp, supra note 45 , at 41 . Forfeiture, outlawry, heriot, and estray were situations in which such rights could be asserted. Id. Heriot entitled the lord to take the villein's best beast at his death even if the villein sold it while alive. Id. at $41 \mathrm{n} .46$.

49. Feudal land claims, which "nested" in the twin hierarchies of tenures and estates, were always claims for the benefit of a personal relationship. Robert C. Palmer, The Origins of Property in England, 3 LAW \& HIST. REV. 1, 5 (1985). They were never claims for possession of a plot of land. Id. A lord could disinherit his tenant for disloyalty, making the tenement extremely precarious. Id. at 6 . While the tenant might complain and feel wronged, the elemental idea in such situations was that of a wrong, not of a property right. Id. at 7 . Righting the wrong 
overlapping claims by many individuals and casual or regular use by persons other than those with particular claims to it, ${ }^{51}$ defied the notion of sole possession ${ }^{52}$ or control for centuries in England and in colonial America.

The modern notion of land ownership evolved as a legal convention (or artifact); ${ }^{53}$ a way for first English, and later colonial, lawyers to resolve

required restoration of the tenement. Id. at 7. These claims were enforceable in the lord's court, later only in royal courts. Id. at 5-7. Those complex personal relationships, and the equally complex land tenures dependent on them, differed substantially from what today are considered property rights, as they were ladened with overlapping hierarchical obligations. Id. at 5; see supra note 46 (discussing hierarchical obligations). As feudalism waned as an organizing principle in England, and with it the diffuse, decentralized authority of individual lords, the Crown took over the protection of rights in property from the lords, but the relational and socially encumbered nature of interests in land remained.

50. An entire hierarchical system of fealty had been built around interests in land during the feudal period in England. Richard J. Lazarus, Debunking Environmental Feudalism: Promoting the Individual Through the Collective Pursuit of Envirommental Quality, 77 Iowa L. REv. 1739, 1742 (1982). In fact, the word "feudum" or "fief" means an object, such as a piece of land, "conveyed with conditions attached." THE HISTORY OF FEUDALISM xiv (David Herlihy ed., 1970), quoted in Lazarus, supra, at 1742. According to Bloch, this system included widespread use of the service tenement instead of salary. This led to extreme subdivisions of property rights in land, as well as in the ties of obedience and protection binding one man to another, and ultimately to the fragmentation of political and governmental authority. $I d$. at 1743 (citing MaRC BLOCH, FeUdAL SOCIETY 446 (1962)); see Frances E. Olsen, The Faxily and the Market: $A$ Study of Ideology and Legal Reform, 96 HARv. L. REv. 1497, 1526-27 (1983) ("[F]eudalism was intentionally hierarchical; feudal society did not subscribe to the belief that people were or should be equal."), quoted in Lazarus, supra, at 1763 n.143; Carol M. Rose, Canons of Property Talk, or, Blackstone's Anxiety, 108 YALE L.J. 601, 603 (1998) [hereinafter Rose, Canons of Property $\mathrm{Tall}_{\mathrm{j}}$ (referring to earlier medieval traditions in which property ownership was hemmed in by intricate webs of military and other obligations). These feudal relationships which were represented and secured by a precarious grant of land involved profound mutual obligations, in which the lord provided protection and maintenance of the tenant in exchange for the tenant's homage. Palmer, supra note 49 , at 4 . The influence of this hierarchical system lasted into the eighteenth century. Gordon, supra note 16 , at 96 .

51. Much of the work of the King's common law courts involved determining which claims (or rights) prevailed in the same parcel of land. Seipp, supra note 45, at 39 .

52. The primary right that defined an individual's relation to a parcel of land, therefore, could be maintained without excluding others. Seipp, supra note 45, at 86-87. English lawyers freely used the term propreté to settle disputes over entitlement to gocids and domestic animals, and over time that term became invested with much of the abstract conceptual force of the modern "property;" droit (right) was the term used for land. Thus, writs of possession applied to goods and domestic animals while writs of right (droit) applied to land. Writs of right were of higher status than writs of possession. Id. at 87-88.

53. See JeREMY BeNTHAM, THE THEORY OF LEgISLATION 113 (C.K. Ogden ed. \& Richard Hildreth trans., 1931) ("Property and law are born together, and die together. Before laws were made there was no property, take laws away, and property ceases."), quoted in Torres, supra note 33, at 1 . Utilitarians, like Bentham, and modern day law and economic scholars find property rights useful because they encourage labor and investment. Rose, Canons of Property Talk, supra note 50, at 619. Rose notes that land, because of its durability, has invited a 
disputes over land in an increasingly mercantile society, in which land began to have value separate from the things it produced (crops, timber) or sustained (domestic animals). ${ }^{54}$ When rights in land finally emerged in England, ${ }^{55}$ they came burdened with social, economic, and political obliga-

layering of rights over time, contrasting land to less durable property like automobiles. Id. This has also prompted doctrinalism, calling for "taxonomic exactitude," and made essential claim-clearing doctrines, like adverse possession and prescription. Id. at 614 .

54. "According to the stylized history, people viewed property as a physical thing or a legal thing until this century, when lawyers recast it as an abstract bundle of legal relations." Heller, supra note 12, at 1188 . Staves makes the point that we only have "property" in things in which the state is willing to discern value. Susan Staves, Chattel Property) Rules and the Construction of Englishness, 1660-1800, 12 L. \& HIST. REv. 123, 152-53 (1994). She further elaborates on this idea by noting that the state is only willing to secure our private goods for us when there is a legitimating rationale or some advantage for the State to justify the expenditure of protective resources. Id. Thus, private property necessarily raises issues of what is in the public interest. She goes on to note that private property is a particular allocation of securities and insecurities, of one person enjoying rights against another person's deprivation of rights, and that political action is necessary to maintain any current distribution of securities or to produce a redistribution of them. Id. Last, she notes that the State's rules about ownership are ultimately rules about personhood and that personal qualities like industriousness and the ability to manage one's own life are differentially ascribed to those who are allowed to own property and those who are not. Id. Freyfogle writes about the "disorienting gap" between land as the artificial thing that a person owns, and land as it is known when we walk outside, that is, land as part of an ecological community that functions independently of humans. Freyfogle, Oumership, supra note 31, at 176; see Eric T. Freyfogle, Ethics, Community, and Private Land, 23 ECOLOGY L.Q. 631, 637 (1996) [hereinafter Freyfogle, Ethics] (noting that far from transcending the human community, private property is very much a product of it).

55. The concept of property in land evolved several centuries after the idea of property in goods and animals. Seipp, supra note 45, at 31 . Development of property doctrines in medieval English common law concerned only controversies about goods and animals and was completely devoid of disputes concerning the possession of land. Id. at 31. Those with possssory rights in goods and domestic animals in the late thirteenth century had the capacity to bring an action in court to protect those rights and to initiate transactions out of court involving the sale or exchange of property. Id. at 49-53, 58-62. In fact, there was not a single term that English lawyers used "that had the scope, application, and explanatory power that later lawyers found in the words 'property' and 'ownership."' Id. at 31. Property was considered to be an attribute of a good (like size, weight or color), and decidedly not a way of talking about or defining a legal right in an object, as it is today, nor was the possession of the good or thing a necessary characteristic of property. For example, "when one person leased a domestic animal to another, the property in the animal remained with the lessor," and property in a stray impounded by a landholder remained with the animal's original owner. Seipp, supra note 45 , at 52; see Francis Bacon, The Learned Reading . . . Upon the Statute of Uses, in 14 THE WORKS OF FRANCIS BACON 283, 319 (James Spedding et al. eds., 1861) ("No man is so absolute owner of his possessions but that the wisdom of the law doth not reserve certain titles unto others."), quoted in Seipp, supra note 45, at 42. By the fifteenth century, English lawyers were recognizing "property" in houses, trees, grain, grass, and minerals; "things" that were affixed to the land yet capable of sale and removal as chattels. Seipp, supra note 45, at 50. But see Palmer, supra note 49, at 8-24 (arguing that property appeared at the end of the feudal period, and that English property common law "took shape" between 1153 and 1215, as the central state began 
tions owed to others. ${ }^{56}$ That sense of communal obligation running with the land also infused early American property law.

The King of England was considered to be in sole possession of the lands in the new colonies.$^{57}$ Some of these lands were granted to individuals or trading companies to develop. The relationship between the grant holder and the individuals who actually settled and cultivated the land was generally one of tenancy. Rents were paid either to the King directly or to the trading company or individual, and then to the King. ${ }^{58}$ Many colonists

to erode the feudal bond between lord and his tenants, and grew out of explicitly social phenomena). An absolute, undifferentiated property interest in land did not emerge in England until the seventeenth century. Id. at 34. Before that, affixing a legal right to a good made sense because it could be possessed exclusively by one person.

Occupancy is the taking of possession of those things that before belonged to nobody. This, as we have seen, is the true ground and foundation of all property, or of holding those things in severalty, which, by the law of nature, unqualified by that of society, were common to all mankind. But when once it was agreed that every thing capable of ownership should have an owner, natural reason suggested, that he who could first declare his intention of appropriating any thing to his own use, and, in consequence of such intention, actually took it into possession, should thereby gain the absolute property of it; according to that rule of the law of nations, recognized by the laws of Rome, quod nullius est, id ratione naturali occupanti conceditur.

2 BLACKSTONE, supra note 2 , at $* 258$ (internal citations omitted).

56. Even in the "idea of property as lordship over one's demesne or household," there was the notion of rights limited by some correlative obligation to protect and support those under the Iord's control. Gordon, supra note 16, at 101. Gordon observes that "as property became reified and redefined as power over things rather than over people" (except with respect to dependents (i.e., wives, children, servants)), "public law constraints upon the patria potestas or mesne lord are gradually removed," leaving absolute dominion unrestrained. Id. at 101-02. This is "an unreviewable fiat authority" within a sphere of rights, defined as freedom. Id. at 102. These rights extend well beyond the household economy, imposing "burdens on evieryone to refrain from infringing on the right, and so invariably restricts freedom," while at the same time, creating it. Id. The property holder is given "the power to dictate terms to others who may want or need access to" his or her land. Id. This power is "backed up by the trespass sanctions" and "the coercive power of the state." $I d$. at 102.

57. In the seventeenth and early eighteenth centuries, land in the colonies was considered to be a part of the demesne of the King, which was his to grant in free and common socage. ROBINSON, supra note 44, at 11 . Socage was a type of land tenure in England under which the tenant held certain types of lands in consideration of certain types of services. BLACK'S LAW DICTIONARY 1389-90 (6th ed. 1990). Free socage, as opposed to villein socage, was where the services were not only certain, but honorable. Id. By law, all the tenures by knight-service, which were the least certain and most precarious, were converted to free and common socage. Id. Gordon notes that the fact that the King theoretically held absolute ownership of all land in the colonies was an obvious deviation from Blackstone's model of landholders having "absolute dominion" over their land. Gordon, supra note 16, at 96. But see infra note 69 (highlighting an area of the colonies in which the form of land ownership was land held in common).

58. The holder of a land grant was a tenant of the King, and owed both fealty to the King 
in the Southeast were originally contract laborers of the Virginia Company, which possessed land under a royal charter. ${ }^{59}$ Later, a tenant-farm policy was put into place in colonies like Virginia to encourage land cultivation and settlement, under which some private use, but not possession, of land was granted. ${ }^{60}$ The pressure to settle land coming from the Crown and the trading companies favored recognizing some form of ownership rights in those who actually worked the land. Tensions soon emerged between those whose title depended on a royal grant and those who had mixed their labor with the soil. . $^{\text {. }}$

The notion of individual property rights in land emerged slowly, as it had in England. ${ }^{62}$ An inhibiting factor in the colonies was that there were two competing bases for legal entitlement to land: ${ }^{63}$ one premised on local usage, a republican concept that favored and rewarded settlement; the other in crown authority, a notion that depended upon the hierarchical feudal concept of the King as the "fountain" of property. ${ }^{64}$ Each theory had

and an annual quit rent to the royal coffers. ROBINSON, supra note 44, at 11. Quit rents replaced military or personal service previously required under feudal law. Id.

59. Provisions in the original charter for the Virginia Company, for example, stated that grants would be made in the name of the King to persons whom the local governing council nominated. Id. at 12. At the time of the dissolution of the Virginia Company, approximately 177 out of 1290 people had obtained land from the Company. Id. at 26. The rest of the colonists lived either as indentured servants or as tenant farmers, who worked off their maintenance or transportation either for the company or for the private individuals who financed their trip to America. Id. at 26. See Brief for Petitioner, King v. Lydius (June 23, 1763), in PaPers OF JOHN TABOR KeMPE, (N.Y. Hist. Soc., Box 5, Misc., Box 3, Sorted Legal Manuscripts), quoted in Elizabeth V. Mensch, The Colonial Origins of Liberal Property Rights, 31 Buff. L. REV, 635, 729 (1982) (stating that it is a "General Principle of Law, that the Crown by the Policy of our Constitution, is the Original Proprietor of all the Lands within the King's Dominion, and that there can be no Right to any Lands within the King's Dominion not derived from the Crown.").

60. Under this policy, tenants needed only to contribute one month of service per year to the colony and an annual fixed amount of corn to the central magazine. RoBinson, supra note 44, at 15-16. Gordon describes these farm tenancies as "ubiquitous type[s] of joint venture[s] among co-proprietors, landlords, and tenants, characterized by partial and collective rights, some created by law, others by contract." Gordon, supra note 16, at 98 .

61. See Mensch, supra note 59, at $643-45$ (noting that New York bar leaders were forced to attempt to integrate Crown control and use of land with colonial township claims based on occupancy and use).

62. See supra note 55 (discussing the evolution of the ideas about property in England).

63. According to Mensch, there were competing definitions of property, one of which was expressed specifically in the vocabulary of title by occupancy, asserted as a voluntarist expression of republican self-reliance; the other title on a grant from the Crown, was conceived as necessary for the hierarchical protection of concentrated wealth. Mensch, supra note 59, at $644-45$.

64. For purposes of this analysis it is important to note that both models of ownership had woven communal obligations into their fabric. The model of ownership based on settle- 
its supporters and detractors, as each served different purposes. ${ }^{65}$ The doctrinal ambiguities and competing utilities of having diametrically opposing legal bases for land claims unsettled title until the Revolution. ${ }^{6}$

Title to land was anything but secure for other reasons as well. Noncompliance with conditions on royal grants often resulted in forfeiture of land to the Crown. ${ }^{67}$ Technical defects in grant language, boundary disputes, ${ }^{68}$ and confusion over how to handle Indian land claims contributed to widespread uncertainty about land rights and led to much legal wrangling. ${ }^{69}$ Further, as in England, ${ }^{70}$ land ownership in many parts of the

ment had strong communitarian strains, while that based on royal grant had traditional ethical responsibilities associated with the feudal model of hierarchy and relational obligations. Id. (describing the competing models as "volunteerism" and "hierarchy").

65. Title based on settlement encouraged cultivation of the wilclerness and the westward expansion of settlers, while title based on royal grant assured a measure of civil order as competing claims among squatters could be quickly and easily disposed of in the face of preemptive crown authority. Id. at 692.

66. See id. at $691-93$ (discussing the ramifications of the doctrinal ambiguity in provincial New York). These differences fueled the land riots that broke out in the $1760 \mathrm{~s}$, when attempts were made to assert title based on prerogative (the Crown's feudal authority) to defease squatters and settlers who claimed title based on a combination of use and Indian deeds. See id. at 727.28 (detailing the riots as described in the papers of John Tabor Kempe, a prominent provincial New York lawyer in the eighteenth century). See Gordon, supra note 16, at 101 (mentioning the large number of land disputes in the eighteenth and nineteenth centuries between settlers, squatters, and adverse possessors, "making Lockean use and occupancy claims to title," and those absent or distant individuals claiming formal title through the Crown, proprietary grants or shares in a trading company).

67. Examples of such conditions were those requiring settlement, payment of quit rents to the Crown, and reservation of pine trees for the royal navy. See id. at 695-97 (discussing Kempe's opposition to such conditions).

68. Boundary disputes were often resolved by legal arguments that undermined the theory that the Crown was the onily legitimate source of legal title. For example, colonial lawyers assiduously avoided resorting to the common law rule that ambiguities with respect to grant boundaries were to be resolved in the Crown's favor or simply declared void and reverted back to the Crown. Mensch, supra note 59, at 701. Mensch finds somewhat startling the peculiar combination of conscientious concern for legality with the "outright" refusal to raise legal arguments that threatened to undercut the conceptual structure of property law in the colonies. Id. at 727.

69. Indian title became an issue when settlers asserted Indian deeds and their own occupancy against a crown grant. According to Mensch, the colonists distinguished between legal title, on the one hand, and squatter title, on the other, fearing that legitinizing the latter would lead to chaos and bloodshed. Equating Indian rights and settler occupancy (squatter title) made sense, as both were considered to be lower rights in contrast to grant rights, which flowed from sovereign authority at the top of the hierarchy. But, because Indian title could be disruptive of settled property expectations, efforts were also made to quash it while still preserving the legitimacy of settler occupancy. See id. at 714-19 (discussing Kempe's involvement in various disputes involving Indian title).

70. For a description of property rights in common under English law, such as the right to pasture animals on another's land, to fish in another landholder's waters, to dig turf and cut 
country was not exclusive, with entire towns laying claim to land in some cases. $^{71}$

And in England, ${ }^{72}$ colonial lawyers were faced with the need to craft an abstract property right to resolve the disputes that clouded title to land

wood, or to cross another man's land with his permission or by prescription, see 2 BLACKSTONE, supra note 2, at *32-36. See also Carol M. Rose, The Comedy of the Commons: Custom, Commerce, and Inherently Public Property, 53 U. CHI. L. REv. 711, 774 (1986) [hereinafter Rose, The Comedy of the Commons](discussing the circumstances in which rights vest in the public); Seipp, supra note 45, at 70-71 (positing that the opposite of having property in goods was sharing goods in common, not necessarily complete divestment). Many land use practices in feudal society had communal trappings, such as the open field system and the village commons, where individuals shared the use of natural resources under prescribed rules regulating their behavior. See generally THE QUESTION OF THE COMMONS: THE CULTURE AND ECOLOGY of Communal Resources (Bonnie J. McCay \& James M. Acheson eds., 1990) [hereinafter THE QuESTION OF THE COMMONS] (examining various case studies where communities in modern times deal with the challenges of managing property held in common).

71. See Mensch, supra note $\mathbf{5 9}$, at $\mathbf{5 4 3}$ (discussing how claims to land by entire townships reflected a complex, collective vision about the role of property in community and religious life). Indians, who enjoyed usufructuary rights in land and used the land for hunting, fishing, or planting crops at specific times of the year, provided a model of land tenure for settlers comparable to what they had left behind in England, in which different groups had some rights to the same land, but no one person owned the land, as we conceive of ownership today, and no one had the right to destroy the land or exclude others from its use. This was particularly true for the Puritans in New England who established villages with common grazing areas, in which rights in land were held in common and the use of and responsibility for land was shared. See generally WILLIAM CRONON, CHANGES IN THE LAND: INDIANS, COLONISTS, AND THE ECOLOGY OF NEW ENGLAND (1983) (describing an ecological history of New England, and how the colonization by Europeans changed the landscape); MITCHELl, supra note 46 (using the example of one plot of land in New England to discuss the impacts of changing ownership from communal to private).

72. Seipp theorizes that property as an abstract concept that could be applied to goods, animals, and land did not materialize in England until the emergence of a merchant class that viewed land-holdings as a source of rental income rather than as inherited entitlement to social and political position. Seipp, supra note 45 , at 89 . These views of land were more easily assimilated with the treatment of property in goods. As land became more property-like, and seen as a source of income rather than a source of interpersonal relationships or a basis for inherited entitlement to social or political status, it became easier to alienate and to extract value from it in new ways, which led to a corresponding need to exclude others. Longrecognized rights of others over the same land began to diminish. Id. at 88-89. Palmer, who contends that property in land first emerged in thirteenth century writs of entry, says that the law regarding property became increasingly artificial, not something that could be equated with traditional procedures or intuited justice. See Palmer, supra note 49, at 4 (tracing the historical development of property in land). But, Palmer cautions, property was not a mere legal phenomenon, an intellectual construct without social relevance. Id. at 47. Property determined the extent of power in post-feudal English society. Id. at 46-47. Palmer also maintains that property, which could only derive from a central state because it required protection by a bureaucratic authority according to set rules, was antithetical to feudal relationships and could not exist prior to the State. Id. at 47. 
although, as noted above, the land disputes in America had a uniquely "colonial" cast to them. To be effective, in the sense of moving uncultivated land into production, this right had to sever the theoretical connection between property and the Crown, yet still be sufficiently absolute and unqualified to resolve the many squabbles among squatters. ${ }^{73}$ The process of abstraction required dramatic new configurations of the legal bases for entitlement to land. ${ }^{74}$ Elizabeth Mensch, who has examined this process of abstraction in New York, found this process to be very slow, resulting in an elusive and precarious meaning of ownership (and private property rights) until the Revolution. ${ }^{75}$

Mensch theorizes that New York colonial lawyers drew from the hierarchical theory of property rights the notion of formal title, protected inequality, and the rhetoric of property as a sphere of autonomy and freedom protected from state imposition. ${ }^{76}$ In the years shortly after the Revolution, these same lawyers took the concept of legal title based on local usage and separated from it the notions of popular sovereignty, which they retained, and voluntary labor and active participation, which they allowed to lapse. They retained the notion of popular sovereignty, but they allowed voluntary labor and active participation to lapse. Rhetorically, property was no longer seen as an expression of civic responsibility, as it was during colonial times, but as an abstract constitutional right ${ }^{77}$ to be asserted against a potentially oppressive sovereign power-the embodiment of hierarchical responsibilities. ${ }^{78}$ Communal norms, a sense of collateral rights and obliga-

73. The legal elite in New York made decisions, which protected proprietors from the Crown's assertion of prerogative authority over land, while also protecting owners against the equally "robust" claims of rights based solely on cultivation and labor. Mensch, supra note 59, at 693. The fear was that either claim threatened an end to secure legal title. The answer was to create a protective barrier between the Crown and colonial landholder, and to simultaneously vest the landholder with sufficiently valid legal title to resist the claims of squatters. Id.

74. Schultz makes the point that the notion of property was appropriated and interpreted by different Founders in different ways, suggesting that property could be described at this point in our history as an "essentially contested concept." Schultz, supra note 43, at $472 \mathrm{n.51}$ (quoting W. B. Gallie, Essentially Contested Concepts, in PROCEEDINGS OF THE ARISTOTELIAN SOCIETY 167 (1956)).

75. Mensch, supra note 59 , at 694 .

76. See id. at 733-35 (concluding that the compromise that blended the two extremes of Crown control of land and control based on productive use of land created our current liberal conception of property).

77. According to Mensch, the ambiguities and tensions surrounding legal title to land were the direct source of the "liberal conception of private, individualized rights" in property, which, by the end of the nineteenth century, had attained the "gothic elegance of classical legalism." Id. at 734.

78. After the Revolution the link between property and liberty was proclaimed, not on behalf of republican communitarianism, but on behalf of hierarchical power relationships, which, by then, had been stripped of the traditional ethical obligations that had been part of 
tions that had once attached to possessory interests in the land, regardless of the source of legal title, disappeared from the post-Revolution vision of property. Also seemingly lost was any notion that these new property "rights" might be less than absolute. New distinctions between the private and public sphere appeared, and with them, the creation of a wedge between the government and individual citizens. ${ }^{79}$

\section{B. ENCUMBERED OWNERSHIP RIGHTS}

The building blocks of basic eighteenth-century social and economic institutions in this country did not include absolute, individual dominion rights over land, ${ }^{80}$ but rather claims to land fragmented and split among many holders, held and managed collectively by many owners. ${ }^{81}$ Personal relationships based on interests in land were ones of dependence and subordination, and interests in land were subject to arbitrary and discretionary destruction at will by others. Even after it emerged as an abstract right, property was surrounded by restrictions on use and alienation, qualified and regulated for communal or state purposes, and destabilized by fluctuating and conflicting regimes of local regulation. ${ }^{82}$ Private property rights

the hierarchical (or feudal) notion of property. Id.

79. After the Revolution, religion and economics were transformed into private (negative) rights protected from the State by the law. "The virtue of the republic came to be defined, especially in legal rhetoric, not by the active moral vigor of the participatory community, but by the strength of that legal barrier." Id. at 735.

80. 2 BLACKSTONE, supra note 2 , at $* 2$ ("[T] hat sole and despotic dominion which one man claims and exercises over the external things of the world, in total exclusion of the right of any other individual in the universe."), quoted in Gordon, supra note 16, at 95. But see Rose, Canons of Property Talk, supra note 50, at 604 (linking Blackstone to a traditional view which ties property to social and political obligations). According to Gordon, to be involved in business at all in eighteenth-century England was to surrender a large sphere of discretionary authority over one's person and property. Gordon, supra note 16, at 99 (quoting Jefferson, who bitterly commented on the commercial credit extended to tobacco-growing Virginia gentlemen by British merchants, as saying "[t]hese debts had become hereditary from father to son, for many generations, so that the planters were a species of property annexed to certain mercantile houses in Britain").

81. Gordon, supra note 16 , at 100 . Gordon makes the interesting point that in eighteenth-century England and America, the deviation between the ideology of absolute dominion over one's property and the unruly pluralism of much lesser rights was recognized in legal practice as "reification." $1 d$. This redefined these lesser rights as estates or as a "thing" in itself so that one held these lesser rights absolutely. Id. Limits on what one could do with one's reified, partial thing were explained as "inhering in the nature of the right that was held." Id.

82. Gordon, supra note 16, at 96 . Property interests (or estates), like entailed fee, and the doctrinal precepts of nuisance and riparian law placed family and "neighborly responsibilities" onto landholders. Rose, Canons of Property Talk, supra note 50, at 603. Rose also notes that the medieval and early modern view of property as "propriety" carried a tradition in which property ownership included a number of responsibilities, including caring for the poor. Id. at 604 
were "subject to significant regulation and expropriation" at the time of the drafting of the Constitution, even though the Revolution ended the era of royal prerogatives ${ }^{83}$ and ushered in a period in which private property and the writings of Locke, ${ }^{84}$ Blackstone, ${ }^{85}$ and Harrington ${ }^{86}$ occupied center stage in the political pamphlets and discourse of the Revolution and its immediate aftermath. ${ }^{87}$ However, the vision of property applied by lawyers, courts, and legislators was quite different from that espoused by the political rhetoricians. The legal vision came from a common law legacy that made property subject to control by the Crown, ${ }^{88}$ restricted mercantile economic policies, and regulated land tenure. ${ }^{89}$ Even Blackstone, who wrote

n.8.

83. Schultz, supra note 43 , at 466 .

84. Schultz suggests that while Locke may have contributed to the "climate of opinion," which framed how many colonists thought about property, it was not until the Jacksonian era that his ideas really permeated political institutions and substantially influenced the law. Id. at 494. Freyfogle points out that Locke added an important, although often overlooked, Proviso to his maxim that the "laborer became the owner of a thing with which he mixed his labor only "where there is enough, and as good left in common for others." Freyfogle, Ethics, supra note 54, at 636 n.18 (quoting JOHN LOCKE, TwO TREATISES OF GOVERNMENT (Peter Laslett ed., 1988)). According to Freyfogle, this Proviso is a critical element underlying the perceived fairness of Locke's claim, and not a mere limitation on it. Id.

85. Blackstone's influence on early American attitudes toward the law was considerable and suggests to Schultz a legalistic reading of property that is far from absolute. Schultz, supra note 43 , at 486 .

86. Schultz notes that Harrington believed that the distribution of property could be altered or regulated to promote republican forms of government, unlike Locke and Blackstone, who proselytized that property rights were absolute and their protection the chief aim of society. Id. at 473-74.

87. Id. at 475-77. According to Schultz, all three vietved property as an important political concept crucial to the maintenance and defense of individual liberty and limited government. Id. at 475 .

88. Before the ascension of the King, relief from adverse property clains could only be had in the lord's court. See generally supra note 49 (discussing the historical concept of land claims). After that, legal title to property, including land, was retained through a hierarchy of writs, most of which eventually became enforceable only in the royal courts. Seipp notes that during the Tudor period, the King became much more proactive, carving out exceptions to common law rules for his special prerogatives. Id. at $\mathbf{8 9 - 9 0}$. Social distinctions among the King's subjects diminished significantly during this period while the gulf between the sovereign and his subjects widened. Id. at 90. Conflicts between the King and his subjects over competing claims in land and goods increased, and English lawyers began to tap into continental political thinking about the right of the prince to take propert' away from his subjects. Seipp, supra note 45, at 90; see Mensch, supra note 59, at 642 ("To avoid the disorder caused by constant assertion of this 'robust' title, however, the use right had been necessarily superseded by the feudal fiction that the ling was the fountain of all property, so that all lands were 'therefore holden either mediately or immediately, of the crown."'). Later, Parliament would become the principle protector of property rights, in some cases from actions of the Crown. Id. at 643 .

89. Schultz, supra note 43 , at $487-91$. 
that property was an absolute right of an Englishman, and whose commentaries were used by Revolutionary pamphleteers and rhetoricians to elevate the importance of individual property rights, framed those rights as conventional, subject to whatever legal limitations were necessary to support the public good, a right "tempered by the law of the land."

Colonial economic regulations significantly encroached onto private property rights, ${ }^{91}$ and government regulation of both dormant and productive land was common. ${ }^{92}$ In Virginia, for example, uncultivated land reverted back to the government for redistribution to more industrious settlers. ${ }^{93}$ Between 1781 and 1801, New York's legislature passed numerous special laws regulating things such as rents and leases, firing of woods, the destruction of deer, stray cattle and sheep, mines, dogs, and fisheries. ${ }^{94}$ Vermont's 1777 Constitution specifically made private property subservient to public uses when necessary to achieve a public purpose, ${ }^{95}$ and colonial governments willingly used eminent domain both before and after the Revolution, often without compensating the landowner for the property taken. ${ }^{96}$ Access easements, either by convenience or prescription, including "public rights" in tidal and submerged lands and in the waterways over

90. Id. at 486 (quoting 2 BLACKSTONE, supra note 2 , at $* 411$ ). Rose argues that Blackstone's opening definition of property as exclusive dominion is only a metaphor, trope, or cartoon designed to make complex systems of rights intelligible, and that reading the rest of what Blackstone had to say about property reinforces the "anxiety" he had about that opening statement. Rose, Canons of Property Talk, supra note 50, at 603-06. But see Epstein, supra note 22, at 22 ("Indeed, it is difficult to conceive of any property as private if the right to exclude is rejected.").

91. Schultz, supra note 43, at 488. Schultz points out that Adam Smith's Wealth of Nations, with its advocacy of laissez-faire economics, was not published in the United States until after 1789. Id. at 489 n. 164 .

92. Id. at 489; see John F. Hart, Colonial Land Use Law and Its Significance for Modern Takings Doctrine, 109 HARV. L. REV. 1252, 1259-81 (1996) (describing colonial regulations); Freyfogle, Ethics, supra note 54, at 640-41 and sources cited therein (explaining that property owners have often been required to make productive use of land, as determined by the community's definition of "productive," or risk forfeiture of the property).

93. ROBINSON, supra note 44, at 54; Hart, supra note 92, at 1260-63.

94. NOVAK, supra note 24 , at 14-15.

95. Schultz, supra notę 43 , at 490 n.173.

96. Id. at 490 . Schultz remarks upon the fact that while some states sought greater protection of property, others saw property as an indication of unwanted privilege, and sought to weaken its protection, citing as examples Pennsylvania and Georgia where there were efforts to weaken property as privilege and to alter property qualifications for voting and officeholding. Schultz, supra note 43, at 490 n.176 (citing RATIFYING THE CONSTTTUTION, 54, 77, 97-98, 103-104, 227 (M.A. Gillespie \& M. Lienesch eds., 1989)). Schultz goes on to observe that even Thomas Jefferson, who espoused the rhetoric of John Locke, nonetheless authored legislation indicating that property rights were neither static nor immune from governmental redistribution or control. Id. at 490 . 
them, were also common. ${ }^{97}$ Traditional individual use-rights, like grazing, wood-gathering, hunting, and fishing, in land designated as commons, are additional examples of deviations from the property regime of absolute, individual dominion..$^{98}$

As late as the 1760s in New York, land grants were conditioned to require that land be settled and cultivated, even as lawyers were crafting an abstract property right that eventually would free property from communal obligations. ${ }^{99}$ Land in townships on Long Island was held on the condition that owners contribute to community projects, such as maintenance of common pastures, road building, and construction of grain mills. ${ }^{100}$ Mensch cites a case from the seventeenth century involving a John Gray ${ }^{101}$ as an example of what happened to property owners who forgot their communal responsibilities. ${ }^{102}$ Gray refused to forfeit part of his land after the community voted to invite new inhabitants from the North which re-

97. See Novak, supra note 24, at 133-134 (citing Palmer v. Mulligan, 3 Cai. 308 (N.Y. 1805) (denying relief to a downstream mill owner from the effects of a newer and larger upstream dam, thereby disallowing one private enterprise to benefit from the use of public waters to the exclusion of others)); see also Veazie v. Dwinel, $50 \mathrm{Me}$. 479, 485 (1835) (saying as to a dispute between private mill owners on the Penobscot River, "[h]ighways, whether on land or water, are designed for the accommodation of the public ... and any unauthorized or unreasonable obstruction thereof is a public nuisance in the judgment of the law. They cannot be made the receptacles of waste material, filth or trash, nor the depositories of valuable property even, so as to obstruct their use as public highways."); Hecker v. New York Balance Dock Co., 13 How. Pr. 549 (N.Y. 1857) (finding a floating dock in New York City's East River a public nuisance and a private appropriation of public waterways).

98. Gordon, supra note 16, at 97. Gordon goes on to explain that "[ $t]$ hese were large 'managed' commons, not states of nature," although management was more likely carried out by neighbors and communities than by an external legal regime. Id. By the end of the eighteenth century in the northeastern and mid-Atlantic colonies, common grazing succumbed to pressure to enclose arable land, while fishermen in New England were more successful in retaining common fishing rights in the river and in using legal policies to balance those rights against the flow rights of mill owners. Id. In the South, open range grazing resisted any attempts at regulation. Id.; see infra text accompanying notes 172-207 (discussing the public trust doctrine).

99. Mensch, supra note 59, at 695. Quit rents and pine tree reserves are examples of other onerous grant conditions. The later presented barriers to settlement and cultivation, but were wanted by the Crown for masts for the royal navy. Id. at 696 .

100. These obligations were not unlike feudal "correes," which were conditions that ran with the land imposed by lords on serfs to perform certain work for the lord, such as plowing fields, harvesting grain, mowing meadows, and repairing buildings; or by the Crown for maintenance of roads, bridges, and dikes. Lazarus, supra note 50, at 1746 n.53.

101. Sentence of John Gray by the Director-General Peter Stuyvesant, Aug. 17, 1654, in DOCUMENTS RELATIVE TO THE COLONIAL HISTORY OF THE STATE OF NEW YORK 286-87 (E. O'Callaghan \& B. Fernow eds., 1853-1887) [hereinafter Sentence of John Gray], quoted in Mensch, supra note 59, at 648 .

102. Id. 
quired the use of his land for their settlement. ${ }^{103}$ Later imprisoned for this offense, Gray admitted his disobedience was the result of an "ungovernable passion, roused by ... [his] belief that the land belonged to him absolutely, by virtue of patent and conveyance, therefore, he had a right to defend and protect it." ${ }^{64}$ The magistrates, before whom he was brought, made him understand that the land was "granted to the village in common," and held by individuals only on the condition that they would, when required, "surrender the patents they had received, and in the interest of the community assert no claim of more right and title in the lands, covered by the patents, than other inhabitants, if more people should come to the village." ${ }^{05}$ Gray was required to surrender his patent for the necessary readjustment, and then ordered to ask God with "uncovered head and bent knees to forgive him" for his defense of absolute individual ownership. ${ }^{106}$

This tradition of intrusive regulation into "the remotest corners of public and private activity" continued well into the nineteenth century. ${ }^{107}$ The courts willingly limited public liability in a host of cases around the country. ${ }^{108}$ They immunized public works from private compensation demands and destroyed previously enjoyed private rights in and uses of property, ${ }^{109}$ particularly those of riparian landowners, in order to assert the preeminence of public powers in newly established public spaces. ${ }^{110}$ In doing

103. Id.

104. Id.

105. Id.

106. Sentence of John Gray, supra note 101, at 286-87.

107. Novak recites as examples of regulatory intrusiveness laws those that Michigan revised in the late 1830 s. NOVAK, supra note 24 , at $15-16$. These laws regulated things such as setting woods and prairies on fire, moving timber on lands or water, capturing stray beasts, and removing nuisances. Id. Michigan also felt free to order railroads to reconstruct bridges for the public welfare, close disorderly houses, and destroy private dwellings when found inimical to the public health or safety. Id. The government did not provide compensation for any of these actions. Id.

108. Novak makes evident that states were far from absent in the "well-regulated society" of nineteenth-century America. Id. at 13-17. From 1787 through 1877, Novak finds a plethora of state regulations that governed public safety and security, the construction of a public economy, and the policing of public space, imposed restraints on morals, and guaranteed public health. Id. at 15. "Public regulation-the power of the state to restrict individual liberty and property for the common welfare-colored all facets of early American development." Id. at 2.

109. As an example of this creativity, Novak cites nineteenth-century state appellate courts which expanded the definition of a public river to include adjacent riparian property so that judges could acquiesce in government-imposed restrictions on the private use of that land. $I d$. at 131-36.

110. See id. at 136 (detailing the actions of these judges). Novak cites the example of French v. Camp, $18 \mathrm{Me} .433$ (1841), in which a riparian landowner was not allowed to cut a hole in the ice near a well-known passageway across the Penobscot River. Id. The court held that this was "a direct violation of that great principle of social duty, by which each one is required to use 
this, the courts reflected the "overwhelming force of an emergent state power over public space, public ways, and natural resources." $" 111$

It is sometimes difficult to fix boundary stones between the private right of property and the police power .... But it is recognized that the State as quasi-sovereign and representative of the interests of the public has a standing in court to protect the atmosphere, the water and the forests within its territory, irrespective of the assent or dissent of the private owners of the land most immediately concerned. ${ }^{12}$

The view of property that crossed the ocean and found root in the colonies, therefore, was not absolute, certain, or exclusive, but was encumbered by communal and political obligations well into the eighteenth century and beyond. Even the emergence of an abstract legal right in property to resolve disputes over land title around the turn of the eighteenth century in states like New York did not strip those rights completely of their communal obligations until much later, nor did it inhibit the State from restricting the use of private land. ${ }^{113}$ Not withstanding Lockean rhetoric, the defense of property rights in the period immediately before and after the drafting of the Constitution was not the main objective of the fledgling government, and property rights were repeatedly sacrificed to support republican principles and the public good. ${ }^{14}$ In light of this historiography, one must marvel at "the power of ideology to structure perceptions of reality in such a way" that the term "property," in modern public speech, has become so "unambiguously a condition of personal autonomy and liberty, without

his own rights, as not to injure the rights of others". Id. at 435 .

111. NOVAK, supra note 24, at 131-36.

112. Hudson Water Co. v. McCarter, 209 U.S. 349, 355 (1908), quoted in Torres, supra note 33 , at 23 .

113. Novak cites numerous examples of what he called "countless" nineteenth-century uses of state police power authority to enact and enforce public laws regulating, in some cases destroying, private rights, interests, liberty, and property for the common good (i.e., public safety, comfort, welfare, morals or health). See generally NovaK, supra note 24, at 13-14 (arguing that Blackstone's definition of "public police and economy" as "the due regulation and domestic order of the kingdom; whereby the individuals of the state, like members of a wellgoverned family, are bound to conform their behavior to the rules of propriety, good neighbourhood, and good manners; and to be decent, industrious, and inoffensive in their respective stations," was very much in force during that period) (quoting 4 WILLIAM BLACKSTONE, COMMENTARIES *162).

114. Schultz, supra note 43, at 490. Novak goes even further than Schultz. After empirically examining nineteenth-century police power regulation, he finds in the "myth of American liberty" a "founding paradox," and concludes that "the storied history of liberty in the United States, with its vaunted rhetoric of unprecedented rights of property, contract, mobility, privacy, and bodily integrity, was built directly upon a strong and consistent willingness to employ the full, coercive, and regulatory powers of law and government." Novik, sufra note 24, at 17. 
having the audience immediately summon to mind its authoritarian connotations."115

\section{EARLY AMERICAN ATTITUDES TOWARD WILD LANDS}

Property, as a legal convention, evolved and changed in other important ways once it was rooted in American soil. During the nineteenth century, courts made significant changes in English common law property doctrines, like waste, adverse possession, trespass, and nuisance, so that the new country's vast, privately owned wilderness could be transformed into cultivated farmland. ${ }^{116}$ These changes favored the industrious landowner who altered the landscape, and not the ones who sought to preserve the status quo. The modified doctrines reflected a hostile attitude toward dormant, wild lands (wilderness), and the animals that inhabited them, that is still with us today.

By the late eighteenth century, only four percent of the total land surface of the modern continental United States had been settled by Europeans. ${ }^{17}$ The balance of the country was sparsely populated. Publicly owned wilderness extended from the Allegheny Mountains west to the Mississippi River, and was preserved, in large part, because of colonial and later federal government policies which discouraged settlement of the western lands as a means of avoiding conflict with hostile Indians. ${ }^{118}$ Later, the fledgling federal government promoted the sale of these wilderness lands as a source of much-needed revenue to finance the operations of the new government and to pay the war debt. ${ }^{119}$ Although squatting was prohibited on the western lands, the passage of the Land Ordinance of 1785 embarked the federal government on a policy of first selling, then giving away the country's land base, awarding squatters preemptive purchase rights to those lands. ${ }^{120}$

The courts, reflecting commonly held beliefs, viewed wilderness harshly, as an impediment to progress. ${ }^{121}$ Judges saw "[t]he country [as] a

115. Gordon, supra note 16 , at 101.

116. John G. Sprankling, The Antiuilderness Bias in American Property Law, 63 U. CHI. L. REV. 519, 521 (1996). Sprankling argues that this country's common law of property can best be explained as an "instrumentalist adaption of English doctrine to American wilderness conditions." Id. at 523.

117. Id. at 526 n.34.

118. See id. at $527-28$ (explaining the reasons why the wilderness was preserved during this period).

119. See id. at 528 (explaining how land policy slowed settlement); see also FEDERAL. PUBLIC LAND AND RESOURCES LAW $82-83$ (George C. Coggins et al. eds., 1993) (describing the history of land sales).

120. See Sprankling, supra note 116, at 526-30 (discussing the evolution of U.S. land use policy).

121. See id. at 530-32 (describing how, as they moved west, Americans were eager to make 
wilderness, and [that] the universal policy was, to procure its cultivation and improvement." ${ }^{122}$ They transformed the English common law doctrine of adverse possession and the rules that required notice to subsequent purchasers, which favored the current owner, ${ }^{123}$ into rules that favored and vested title in the industrious interloper. ${ }^{124}$ Courts enhanced the legal protections afforded a mistaken improver of another's land, and altered the doctrines of trespass ${ }^{125}$ and nuisance to encourage use of wilderness lands.

In the process of reformulating English common law to promote the transformation of wilderness into cultivated land, American courts not only made it easier for individuals to become landowners, but did so in a way that rewarded those who converted fallow (or wild) land to productive use. ${ }^{126}$ An altered common law regime helped fuel the transformation of

use of land). Sprankling goes on to say that this utilitarian ideology spawned an American judicial attitude that strongly favored agrarian development of wilderness lands. Id. at 532 .

122. Van Ness v. Pacard, 27 U.S. (2 Pet) 137, 145 (1829), quoted in Sprankling, supra note 116, at 525-26. Mensch notes that, in the Massachusetts Bay colony, for example, a legal right to land could be based only on cultivation, not on mere hunting and fishing. Mensch, supra note 59 , at 686 .

123. Sprankling, supra note 116, at 526. Although the common law of "post-wilderness" England also emphasized the productive use of land, it encouraged the continued use of developed land, not the destruction of uncultivated or wild lands. Id. at 533. American property law, which was designed to stimulate the creation of productive land out of the destruction of wilderness, was thus fundamentally different from its English common law roots. Id. at 532-33.

124. Staves makes the additional point that the English colonists used the argument that the uncultivated land owned by Indians was being wasted, and could, in British hands, be improved for the benefit of all to justify their appropriation of that land. Staves, supra note 54, at 141. Locke's Tuo Treatises on Civil Government, according to Staves, managed to read all nonEuropean indigenous inhabitants of these waste lands out of the social contract, thus making indigenous lands available for European colonization. Id. "[Y]et there are still great Tracts of Ground to be found, which (the Inhabitants thereof, not having joyned with the rest of Mankind, in the consent of the Use of their common Money) lie waste, and are more than the People who dwell on it do, or can make use of, and so still lie in common." LOCKE, supra note 84, quoted in Staves, supra note 54, at 141.

125. Mensch notes that by the mid-eighteenth century the law no longer favored the trespasser, which reflected the increasing priority given to grant (or legal) title over title based on occupation and use. Mensch, supra note 59, at 725. Where in the seventeenth century, it had been clear that unfenced land could be used by all for wood, lime, and other necessities, a Colonel Bradstreet, who had been charged with entering an unused pasture to take wood for boat construction, was told that if the acts of trespass had been performed as alleged, then "your defense must consist entirely in endeavoring to mitigate the Damages." Letter from John Tabor Kempe to Col. Bradstreet, Sept. 9, 1765, in Papers of John Tabor Kempe, N.Y. Hist. Soc. Box 5, Misc., Lawsuits A-B, quoted in Mensch, supra note 59, at 725.

126. Blackstone believed that forests and "other waste grounds," even though frequently found without a specific ormer, and thus potentially subject to the property rule of first acquisition, are most wisely vested in the sovereign or in his representatives, usually the lord of the manor. 2 BLACKSTONE, supra note 2, at $\$ 14-15$. According to Blackstone, vesting waste grounds in the sovereign avoided disturbances and quarrels, "[a]nd thus the legislature of 
the natural landscape throughout the eighteenth and nineteenth centuries, as the vast savannahs fell first to the pioneer's plow, then to McCormick's reaper, ${ }^{127}$ and finally, in the twentieth century, to bulldozers planting the last row crop, houses. ${ }^{128}$ The common law, mutatis mutandi, protected and fostered privatization of the wild landscape, ${ }^{129}$ and reflected a historical antipathy toward wild lands, remnants of which can be found in the resistance of modern landowners to preservation of wildlife habitat. ${ }^{190}$

England has universally promoted the grand ends of civil society, the peace and security of individuals, by steadily pursuing that wise and orderly maxim of assigning to every thing capable of ownership a legal and determinate owner." Id.

127. According to Sprankling, Locke's labor theory of property found purchase not only in Jefferson's yeoman farmer, but later in Jacksonian populist government institutions. Sprankling, supra note 116 , at 528 .

128. Another example of the transformative changes to both the legal regime and the physical landscape was the evolution of the common law rules governing water, which eventually paved the way for the deserts to bloom with tract housing, swimming pools, and golf courses. Under traditional common law doctrines, water had belonged to no one, and individual users could not impair the overall health of watercourses. A. DAN TARLOCK, LAW OF WATER RIGHTS AND RESOURCES, $\S 3.02$ [1] 3-4-3-5 (1999). However, the scarcity of water in the western United States, and the uses to which it was put, such as mining, agriculture and ranching, necessitated a change in the common law which allowed water to become the sole property of the industrious user. Id. at § 5.01[1]5-5-5-6; see ROBERT G. DUNBAR, FORGING NEW RIGHTS IN WESTERN WATERS 59-85 (1983) (discussing the transformation of water law in the West from riparianism to a doctrine of prior appropriation); Sipriano v. Great Spring Waters of Am., Inc., I S.W.3d 15, 75 (Tex. 1999) (refusing to abandon the rule of capture, which allows a landowner to pump as much groundwater as she chooses without liability to neighbors who claimed the pumping had depleted their wells, in favor of the common law rule of reasonable use, which would have limited the amount of water a surface owner can take to that amount that does not unreasonably harm landowners who also draw water from that same source).

129. Property law in the West was quite fungible, often adapting to meet local exigencies, like the law of the mining camps which recognized the possessory rights of claim jumpers. See Cole v. Ralph, 252 U.S. 286, 295 (1920) ("[B]ut if his occupancy be relaxed or be merely incidental to something other than a diligent search for minerals and another enters peaceably and not fraudulently or clandestinely and makes a mineral discovery and location, the location so made is valid and must be respected accordingly."); Davis v. Nelson, 329 F.2d 840 (9th Cir. 1964) (holding that although the occupation and working of a claim gives the prospector a limited defendable right of possession, this right is alienable because the discovery of the valuable mineral is what gives the prospector the ability to make the claim on the land).

130. Modern courts are somewhat more inclined to see important social and economic values in undeveloped land, such as wilderness. See United States v. Riverside Bayview Homes, 474 U.S. 121 (1983) (recognizing the ecological value of wetlands); Marks v. Whitney, $6 \mathrm{Cal}$. 3d 251, 259-60 (Cal. 1971) ("There is a growing public recognition that one of the most important public uses of the tidelands ... is the preservation of those lands in their natural state, so that they may serve as ecological units for scientific study, as open space, and as environments which provide food and habitat for birds and marine life."); Just v. Marinette County, 201 N.W.2d 761, 768 (Wis. 1972) ("Swamps and wetlands were once considered wasteland, undesirable, and not picturesque. But as the people became more sophisticated, an appreciation was acquired that swamps and wetlands serve a vital role in nature, are part of the balance 


\section{EARLY AMERICAN COMMON LAW DOGTRINES AFFECTING WILDLIFE AND WILDLIFE HABITAT}

Unlike the changes that were made to common law property doctrines to facilitate the transfer of uncultivated land to productive individuals, the English conceptualization of wildlife as res communes (belonging to no individual, like the air and oceans) and ferae naturae (animals which by their nature are wild) ${ }^{131}$ and common law doctrines that applied to wildlife took root in this country and endured largely without change. ${ }^{132}$ English laws,

of nature and are essential to the purity of the water in our lakes and streams.").

131. From Roman times forward, wild animals were considered to belong to no one, and to be the subject of common ownership, but unlike air and oceans, individual property could reside in wildlife that had been reduced to capture. See generally J. C. THOMAS, TEXTBOOK ON ROMAN LAW 167 (1976) (discussing gaining ownership of wild aninals). Under English law, which built upon the Roman legal tradition, the sovereign held an exclusive prerogative to animals over and above the interests held by individual landowners. 2 BLACKSTONE, supra note 2, at $\$$ 17-18. For a discussion of ancient and early English attitudes toward taking and protecting wildlife, see generally MiCHAEL J. BEAN \& MELANIE J. ROWLAND, THE EvoluTiON OF NATIONAL WILDLIFE LAW 7-10 (3d ed. 1997); Field, supra note 41, at 459-64; and Dean Lueck, The Economic Nature of Wildlife Law, $18 \mathrm{~J}$. LEGAL STUD. 291, 292-95 (1989).

Wildlife engendered some of the most spirited debates among medieval English lawyers about the nature of property, and disputes about the taking of wild game animated the earliest discussions about property and property rights. The puzzle for fourteenth and fifteenth-century English lawyers was how property could be acquired in captured (or killed) wild animals that previously had not belonged to anyone. The legal debate over who possessed the captured animal, the landowner or the hunter who chased the animal onto the land and then killed it, continued well into the seventeenth century. Seipp, supra note 45, at 83-84; see Pierson v. Post, 3 Cai. 175 (N.Y. 1805) (stating that property in a fox belongs to the person who intercepted and killed it); 2 BLACKSTONE, supra note 2, at *14 (noting that only a usufructuary property can be had in wild animals, light, air, and water, and thus they belong only to the first possessor while he is in possession of them and no longer). According to Seipp, commentators, like Bracton, relied on the Roman concept that wild animals (ferae naturae) were nullius in bonis (among the property of no person) or nullius in rebus (owned by no one), and stressed the element of capture in the acquisition of property in them, while lawyers reasoned from the labor or industry expended in the chase or in the domestication of wild animals. Seipp, supra note 45 , at 64 . The notion that property includes living wild animals existed only briefly in the English lawyer's mind, and only with respect to claims by fifteenth-century landholders that they had property in wild animals for the time the animals remained on their land. This concept gave landholders the legal authority to grant rights to hunt on their land and to hold bailiffs accountable for any depredation in wildlife stocks. Id. at 50,64 . In contrast, game dogs in seventeenth- and eighteenth century England were considered to be private property, but only of those who met minimum property requirements. Staves, supra note 54, at 140 .

132. The extent to which judges relied on English common law doctrines with respect to wildlife is apparent in Pierson v. Post, in which both the majority and dissenting opinions spent considerable time examining those doctrines. See 3 Cai. 175, 179 (N.Y. 1805) (holding that the common law favored lodging proprietary rights in the individual who killed the fox); see also Pollard v. Hagen, 44 U.S. (3 How.) 212 (1845) (applying English common law to determine water rights); Martin v. Waddell, 41 U.S. (16 Pet.) 367 (1842) (relying on English common law 
which gave the Crown complete authority to determine the rights of landowners with respect to wildlife management, ${ }^{133}$ also became part of the common law of the colonies and eventually that of the several states which assumed the Crown's responsibility to act "as trustee to support the title [to wildlife] for the common use."134 Although most of these early English laws were not designed to protect wildlife, ${ }^{135}$ lawmakers occasionally acted to alleviate man-made changes to the natural landscape that endangered desirable species, ${ }^{136}$ or to prohibit particularly destructive methods of taking

in ejectment action).

133. While English lawyers argued about who had the right to claim felled game, the right to catch (or take) game was an undisputed prerogative the King handed out to his favored nobility. Seipp, supra note 45, at 61 . Lord Edward Coke, in his Reports, repeated as a rule of common law the general maxim, "when no man can claim property in any goods, the King shall have them by his prerogative." Id. at 81 ; see 2 BLACKSTONE, supra note 2 , at $* 417-18$ ("TT] he sole right of taking and destroying game belongs exclusively to the king."). The practice of granting franchises, particularly with regard to fisheries, became so extreme that in 1215, the Magna Carta ordered removal of fishing weirs throughout England. Field, supra note 41, at 461; see BEAN \& ROWLAND, supra note 131, at 9 (describing the establishment of fishery franchises); R.H. Helmholz, Magna Carla and the Ius Commune, 66 U. CHI. L. REv. 297, 355-56 (Summer 1999) (citing Chapter 33 which required removal of obstructions to navigation in the Thames, the Medway, and throughout all England, to achieve free movement on the rivers). Field notes that early English law first allowed free access to wild animals without interference from the Crown. Field, supra note 41 , at 461 . For a lengthy discussion of the complex rules that applied to different types of game and fish, and different property rights in both the game and the land on which it could be found, including those that originated as "a flower of the prerogative, till restrained by magna charta," see 2 BLACKSTONE, supra note 2 , at *38-40. These royal rights were reflected in a web of laws that assured the sovereign's control over both the game and over the lands on which the game depended. Penalties for violating these laws were extreme. For example, poaching was punishable by death or by castration and banishment. Field, supra note 41, at 461; see BEAN \& ROWLAND, supra note 131, at 10 (describing qualification statutes that outlawed hunting by people of low-class rank); 2 BLACKSTONE, supra note 2, at *403 (describing restrictions on mankind's natural right:

[to] pursue and take any fowl or insect of the air, any fish or inhabitant of the waters, and any beast or reptile of the field ... [on the taking of] royal fish, as whale and sturgeon, and such terrestrial, aerial, or aquatic animals as go under the denomination of game; the taking of which is made the exclusive right of the prince, and such of his subjects to whom he has granted the same royal privilege).

134. Arnold v. Mundy, 6 N.J.L. 1, 70 (N.J. 1821); see generally Thomas A. Lund, Early American Wildlife Law, 51 N.Y.U. L. REv. 703 (1976) (discussing the development of American wildlife laws and policies during the period 1625-1825).

135. According to Field, most of the early English laws regulating the taking of wildlife were designed to further "elitist," not conservationist, goals, by distinguishing among various social castes and apportioning rights accordingly. Field, supra note 41 , at 461 . Thus, only citizens "qualified" by birth and wealth could take game, and possess and use certain hunting weapons. See id. at 461.62 (discussing "qualification" statutes).

136. See id. at 462 n.36 (mentioning a 1393 English law that required weirs in dams to allow spawning runs of anadromous fish). 
wildlife. ${ }^{137}$ In doing this, they showed a prescient awareness of the connection between habitat and species preservation, and a willingness to restrict human activities on lands important for purposes of wildlife preservation. ${ }^{198}$ For example, early English laws established preserves, comparable to modern wildlife refuges, "of woody grounds and fruitful pastures, privileged for wild beasts and fowls of forest, chase, and warren, to rest and abide there in safe protection of the King for his delight and pleasure," where sheep, goats, and cattle could not graze. ${ }^{139}$

Two state common law doctrines still in use today, the wildlife trust and public trust doctrines, incorporate these earlier English mores and understandings respecting wildlife. They also support the conclusion that, even after Lucas, wildlife laws fall outside the reach of the Just Compensation Clause. ${ }^{140}$

137. The near extirpation of the British wolf during the reign of King Edgar and King Canutus led later lawmakers to take steps to protect desirable species and prevent particularly destructive methods of hunting. Id. at 462.

138. Id. at 461-62. Sprankling labels England's property law system as "semipreservationist law," focused on preserving the quality of lands already devoted to productive use in a mature agrarian economy in order to save country's dwindling forests, which provided timber for the country's navy. Sprankling, supra note 116, at 524-25. See supra text accompanying notes 113 127 (discussing early American attitudes toward wild lands).

139. J. MANWOOD, TREATISE OF THE FOREST LAW 143 (W. Nelson ed., 4th ed. 1717), quoted in Field, supra note 41 , at 463 . In these preserves, which existed outside the common law, special doctrines protected the wildlife, special officials enforced the application of these doctrines, and special courts heard disputes involving their application. Id. For example, the doctrine of special vert protected vegetation in the preserves for deer to feed on, the doctrine of nocumentum forestae restricted the cutting of plants that provided cover for forest wildlife, and the doctrine of nocumentum speciale prohibited actions which directly injured wildlife. Id. at 463-64. An additional example of preservationist policies is found during the reign of the Norman Kings, who ordered farmland to be returned to forest to provide habitat for deer and other game. Id. at 461.

140. Economists have also examined the appropriateness of compensating landowners for dimunition in property values attributed to laws protecting wildlife. Robert Innes, Stephen Polasky, and John Tschirhart explore both Coasean and non-Coasean logic in trying to derive an answer to whether compensation should be paid for regulatory takings, what form that compensation should take, and whether there is a need for judicial (or constitutional) restraint to ensure that the government has an incentive to choose efficient takings and compensation policies. See Robert Innes et al., Takings, Compensation, and Endangered Species Protection on Privale Lands, 12 J. ECON. PERSP. 35 (Summer 1998). The authors conclude that a constitutional requirement for compensation has a number of drawbacks, including its political unpopularity, which may discourage protecting wildlife species, and that it may' be unnecessary because the government has an incentive to design an efficient protective policy without any judicial restraint. Id. However, judicial restraint in the form of the compensation may be appropriate where the government decides to distribute economic largess to meet political ends and not to reflect the societal benefits of earlier protective decisions, what law and economics scholars would derogatorily call "rent-seeking." Id. 


\section{A. THE STATE WILDLIFE TRUST DOCTRINE}

Wildlife management in this country has been a prerogative of government since colonial times, as it was in England, and, as in England, laws regarding wildlife have helped define private property rights. ${ }^{141}$ Late seventeenth- and early eighteenth-century colonial laws opened private property to hunters and fishers, for instance, allowing them passage across private lands to reach interior lakes. ${ }^{142}$. These laws established the legal presumption that landowners welcomed hunters and fishers, ${ }^{143}$ and withheld from landowners the most basic of the perquisites of ownership, the right to exclude. ${ }^{144}$ During the same period, laws restricted the free taking of wildlife to conserve various species, and regulated trade in wildlife. ${ }^{45}$ Later, during the nation's westward expansion, instrumentalist courts transformed private land into grazing commons as a way of legitimizing livestock trespass. ${ }^{146}$ These laws and policies were repeatedly sustained, first by colonial

141. See generally, supra note 131 (discussing the historical legal framework of wildlife law, and its impact on property law in general).

142. Field, supra note 41 , at $465-66$.

143. These early laws reflected a policy of "free-taking" of wildlife that reflected the abundance of wildlife, the immense size of the country, and the frontier spirit of the early settlers. Id.

144. Hart, supra note 92, at 1252; see McKee v. Gratz, 260 U.S. 127 (1922) (finding an implied license to trespass in the American custom of allowing hunters and fishers to wander, shoot, and fish at will); Bizzell v. Booker, 16 Ark. 308, 320 (Ark. 1855) (noting that the rule that hunting in privately owned wilderness did not constitute a trespass originated because "[d]rafts upon the forest game, are also often required to supply the wants of the pioneer, under the contingencies and inconveniences of a sparsely inhabited country"); In re Delaware River at Stilesville, 131 A.D. 403 (N.Y. App. Div. 1909) (rejecting landowner's challenge to a state requirement that he construct a fish ladder, saying "[t]he people of the state have as an easement in the stream the right to have fish inhabit its waters and freely pass to their spawning beds and multiply ... and no riparian proprietor upon a stream has the right to obstruct free passage of the fish to the detriment of other riparian proprietors or of the public"); id. at 465-66 (noting that lawmakers opened private lands to the public, presuming that landowners welcomed hunters and fishers).

145. Id. at 464-68; see BEAN \& RowLAND, supra note 131, at 10-15 (noting that by the end of the nineteenth century, every state and territory had laws regulating the taking of fish and game and that the nascent conservation movement, fueled by the writings of Ralph Waldo Emerson, Henry David Thoreau, and Francis Parkman as well as the work of naturalists like John J. Audubon, contributed to the enactment of these laws).

146. A western equivalent of this instrumentalist attitude toward undeveloped land can be found in the "twin themes" of grazing - that grazing was both free by custom and necessary to encourage the economic use of wilderness areas. Sprankling, supra note 116, at 551. This attitude, in turn, legitimized livestock trespasses. Id.; see Buford v. Houtz, 133 U.S. 320, 327 (1889) (emphasizing the importance of allowing settlers "to graze their stock upon ... the unenclosed lands of the private individual"); MacKay v. Uinta Dev. Co., 219 F. 116, 119 (8th Cir. 1914) (holding nomadic shepherd not liable for damage done by his sheep as he trailed them across checker boarded private lands while going to and from pasture on public lands 
courts and later by the courts of the several states and territories. The continuing vitality of these maxims in the common law of the several states provides a basis for contending that laws that reify these principles fit within the Lucas exception.

The Crown's transcendent interest in wildlife evolved into the legal principle that the State "owned" wildlife. ${ }^{147}$ The U.S. Supreme Court affirmed this maxim at the end of the nineteenth century in Geer $v$. Connecti$\mathrm{cut},{ }^{148}$ thereby preventing title to wild animals from vesting in any individual. ${ }^{149}$ The Geer Court characterized the State's preeminent right to "control and regulate the common property in game" as a "trust" for the benefit of its citizens ${ }^{150}$ and based its affirmation of states having complete authority to condition the killing and sale of game "on the peculiar nature of such property and its common ownership by the citizens of the State."151 Even though the Supreme Court in Toomer v. Witsell ${ }^{152}$ labeled the idea that the State owned wildlife "a fiction expressive in legal shorthand of the importance to its people that a State have power to preserve and regulate the exploitation of an important resource," 153 courts relied on what became known as the "state ownership doctrine" to sustain state wildlife laws regulating the taking of game until the middle of the twentieth century. ${ }^{154}$ For

because the total parcel had the appearance of a "common," and saying, "wholesome legislation', may be constitutionally enacted though it lessens in a moderate degree what are frequently regard as absolute rights of private property,") (quoting Camfield v. United States, 167 U.S. 518,524 (1897)).

147. BEAN \& ROWLAND, supra note 131, at 10-11; see People v. Chambers, 398 N.Y.S.2d 222, 223 (N.Y. 1977) ("[O]wnership of fish and game, within the Stare, is in its sovereign capacity and the State has the general right to protect fish and game."); Sloup v. Town of Islip, 256 N.Y.S.2d 742, 745 (N.Y. 1974) ("Migratory marine fish are ferae naturae and are the property of the state."). Amold v. Mundy is often cited for the proposition that the King's prerogatives over wildlife (later Parliament's) were transferred to the individual states after formation of the Union. 6 N.J.L. 1 (N.J. 1821). For an expansion of the idea into federal property interests see Palila v. Haw'iii Dep't of Land E Natural Resources, 471 F. Supp. 985, 995 n.40 (D. Haw. 1979) (noting that the importance of preserving a natural resource like an endangered species may be "of such magnitude as to rise to the level of a federal property interest").

148. 161 U.S. 519 (1896).

149. Id. at 526-27; see Missouri v. Holland, 252 U.S. 416 (1920) (holding that migration of wild birds is a national issue, and therefore the state ownership is limited because no Tenth Amendment rights of states will prevent the national government from entering a treaty to prohibit the killing and capture of certain birds).

150. Geer, 161 U.S. at 598-29 (stating that the right to "control and regulate the common property in game" is exercised by the states "as a trust for the benefit of the people"); see generally Lueck, supra note 131, at 295-96 (examining the relationship between wildlife law and the value of property).

151. Geer, 161 U.S. at 530.

152. 334 U.S. 385 (1948).

153. Id. at 402 (emphasis added).

154. Courts addressing the validity of vildlife laws, as in Mailland v. People, 23 P.2d 116 
example, in Maitland v. People, ${ }^{155}$ the Colorado Supreme Court upheld a fine levied against a landowner for killing a deer on his private land within a state-designated game refuge, saying:

The power of the state to make regulations tending to conserve the game within its jurisdiction "is based largely on the circumstance that the property right to the wild game within its borders is vested in the people of the State in their sovereign capacity; and, as an exercise of its police powers and to protect its property for the benefit of its citizens, it is not only the right but it is the duty of the State to take such steps as shall preserve the game from the greed of the hunters." 156

Hughes v. Oklahoma ${ }^{157}$ overruled Geer in 1979 , but only on the narrow issue of the State actually owning wildlife. ${ }^{158}$ At issue in Hughes was whether a state's proprietary interest in wildlife could burden interstate commerce. For the Commerce Clause to prevail, the Court had to dispose of the State's property interest in wildlife, which it did by reiterating the language in Toomer that state ownership of wildlife was "no more than a 19th-century legal fiction." ${ }^{159}$ But, at the same time, the Court pointedly noted that that fiction expressed "the importance to its people that a State have power to

(Colo. 1933), frequently conflated the state ownership doctrine with the State's general police powers, considering them to be potentially interchangeable bases for regulations protecting wildlife.

155. Id.

156. Id. at 117 (citation omitted); see Rogers v. State, 491 So. 2d 987, 989-90 (Ala. Crim. App. 1985) (" $[T]$ he authority of the state to regulate the hunting of its game animals derives from the long established and well recognized principle of law that ownership of wild animals is vested in the state.") (citations omitted); Rice Hope Plantation v. South Carolina Pub. Serv. Auth., 59 S.E.2d 132, 142 (S.C. 1950) ("[E]very landowner has, as an incident to the ownership thereof, the right to hunt and fish thereon, subject to reasonable governmental regulations, although game and fish are really the property of the State, and the preservation thereof is a matter of public interest."); Fields v. Wilson, 207 P.2d 153, 156 (Or. 1949) (stating that wild 'animals [are] 'ferae naturae,' and while in a state of freedom their ownership, so far as a right of property can be asserted, is in the state, not as a proprietor, but in its sovereign capacity for the benefit of and in trust for its people in common") (quoting Monroe v. Withycombe, $165 \mathrm{P}$. 227, 229 (Or. 1917)); Cook v. State, 74 P.2d 199, 202 (Wash. 1937) ("[A]ll property rights in ferae naturae were in the sovereign. The killing, taking, and regulation of game and other wild life were subject to absolute governmental control for the common good. This absolute power to control and regulate passed with the title to the game and wildlife to the several states subject only to the applicable provisions of the Federal Constitution.") (emphasis added).

157. 441 U.S. 322 (1979).

158. According to Houck, Hughes did not (and could not) overrule the principle, dating back to Roman law, that wild animals are the common property of the citizens of a state (res communes), and that states have a trust responsibility to ensure the perpetuation of wildlife. Houck, supra note 23, at 311 .

159. Hughes, 441 U.S. at 335. 
preserve and regulate the exploitation of an important resource," and specifically said that the "overruling of Geer does not leave the states powerless to protect and conserve wild animal life within their borders." 160 Indeed, the Court in Hughes emphasized that its decision would not impede the legitimate state interest in protecting wildlife resources. ${ }^{161}$

Although the legal fiction that the State owns wildlife may have largely disappeared from judicial decisions supporting state authority to regulate wildlife. ${ }^{162}$ Hughes neither disturbed the common law canon of the State's preeminent interest in and responsibility for preserving wildlife undergirding that fiction, nor did it disturb the idea that the State acts on behalf of its citizens when it takes steps to preserve wildlife. ${ }^{163}$ Courts continue to rely on these common law maxims to justify a broad range of state powers to manage and protect wildlife, including the power to protect important

160. Id. at 338 .

161. Id. at 335-36 ("The general rule we adopt in this case makes ample allowance for preserving, in ways not inconsistent with the Commerce Clause, the legitimate state concern for conservation and protection of wild animals underlying the 19th-century legal fiction of state-ownership.").

162. But see Rogers v. State, 491 So. 2d at 989-90 (Ala. Crim. App. 1985) (referring to the "long established and well recognized principle of law that ownership of vild animals is vested in the state"); Shepherd v. State, 897 P.2d 33, 39-41 (Alaska 1995) (noting that the state ownership doctrine applies absent conflict with paramount federal interests). Accord State v. Fertterer, 841 P.2d 467, 470-71 (Mont. 1992) (rejecting the argument that Hughes effectively precluded reliance on "the long established and well recognized principle of law that ownership of wild animals is vested in the state"). Thirty-one states also still claim title to resident fish and wildlife, in their constitutions or laws, indicating that some long-held understandings die hard. Houck, supra note 23, at 309 n.76 (citing RuTH S. MUSGRAve \& IMARY ANNE STEIN, STATE WILDLIFE LAWS HANDBOOK (1993)).

163. Hughes, 441 U.S. at 335-36, 339; see Pullen v. Ulmer, 923 P.2d 54, 60 (Alaska 1996) ("After Hughes, the statements in the Alaska Constitutional Convention regarding sovereign ownership ... are technically incorrect. Nevertheless, the trust responsibility that accompanied state ownership remains.") (quoting Owsichek v. State, Guide Licensing and Control Bd., 763 P.2d 488, 495 n.12 (Alaska 1988)); Shepherd v. State, 897 P.2d 33, 40 (Alaska 1995) (noting that "the state acts as 'trustee' of the naturally occurring fish and wildlife in the state for the benefit of its citizens") (quoting State v. Ward, 40 S.W.2d 1074, 1077 (Mo. 1931)); State v. Bartee, 894 S.W.2d 34, 41 (Tex. App. 1994) (stating that the common law of Texas and the rest of the United States is that "the general ownership of wild animals, as far as they are capable of ownership, is in the state, not as a proprietor, but in its sovereign capacity as the representative and for the benefit of all its citizens in common"); see generally Douglas F. Britton, The Privatization of the American Fishery: Limitations, Recognitions, and the Public Trust, 3 OCEAN \& COASTAL L.J. 217, 236 (1997) (concluding that while fish are in the public waters of the state, fishermen have no compensable property rights under the Fifth Amendment); 35 AM. JUR. 2D Fish $\dot{\sigma}^{2}$ Game $\$ 1$ (1967) (explaining that, as long as fish and game are ferae naturae, they are owned by the state in its sovereign capacity for the benefit of all, and the ability of the state to regulate hunting and fishing comes from the fact that the individual's right to take game is a privilege granted by the state which may be taken away or limited). 
wildlife habitat, ${ }^{164}$ sustain warrantless searches on private lands to enforce fish and game laws, ${ }^{165}$ and allow states to recover money damages for injuries done to fish and wildlife. ${ }^{166}$ The same principles have protected state authorities from Fifth Amendment takings claims when they restrict the killing or harming of game.

The right to kill game is a boon or a privilege granted, either expressly or impliedly, by the sovereign authority, and is not a right inhering in any individual. Consequently, nothing is taken from the individual and his constitutional rights are not infringed when he is denied the privilege or when limitations are placed on the killing or marketing of game. ${ }^{167}$

164. See Columbia River Fisherman's Protective Union v. City of St. Helens, 87 P.2d 195, 198 (Or. 1939) (explaining that the public authority to protect wildlife would be to "no avail" if the public did not also have the power to protect important wildlife habitat from destruction). Accord Township of Grosse Ile v. Dunbar \& Sullivan Dredging Co., 167 N.W.2d 311, 316 (Mich. Ct. App. 1939) (upholding rezoning which prevented owner of island and adjoining riparian rights from dumping fill in river as within the reasonable exercise of state power to protect fish and game habitat); Barrett v. State, 116 N.E. 99, 100 (N.Y. 1917) (sustaining constitutionality of state law prohibiting the disturbance of "any wild beaver or the dams, houses, homes, or abiding places of same") (citing 1904 N.Y. Laws 674 \$1).

165. See Betchart v. California State Dep't of Fish \& Game, 205 Cal. Rptr. 135, 137 (1984) (affirming warrantless search of private lands because California wildlife is publicly owned); State v. McHugh, 630 So. 2d 1259, 1264 (La. 1994) (approving warrantless random stops of boats by state wildlife agents to check for violations of waterfowl bag limits, and saying " $[t]$ here can be no doubt that the state's interest in safeguarding the wildlife and fisheries for the benefit of the people is compelling"). Accord State v. Tourtillott, 618 P.2d 423, 430 (Or. 1980) (affirming constitutionality of "game check point," and emphasizing that the "governmental interest in the enforcement of laws for the preservation of wildlife" was substantial).

166. State $e x$ rel. Bacich v. Huse, 59 P.2d 1101, 1103 (Wash. 1936) (stating that the doctrine authorize states to exercise powers over these resources "as absolute as that of any other owner over its property"); see also In re Steuart Transp. Co., 495 F. Supp. 38 (E.D. Va. 1980) (recognizing right of state and federal governments to sue for damages to public wildlife resources caused by oil spills); Attorney Gen. v. Hermes, 339 N.W.2d 545 (Mich. Ct. App. 1993) (recognizing that public ownership rights in fish support action for damages by Attorney General based on harvesting of fish in violation of state fishing regulations); State v. Gillete, 621 P.2d 764, 767 (Wash. Ct. App. 1980) (affirming award of damages in favor of the State Department of Fisheries against a landowner who destroyed salmon eggs by running a tractor through a stream bed on his land, stating "the food fish of the state are the sole property of the people and the state, acting for the people, is dealing with its own property, "over which its control is as absolute as that of any other owner over his property") (quoting State ex rel. Bacich, 59 P.2d at 1103).

167. Fields v. Wilson, 207 P.2d 153, 156-57 (Or. 1949) (quoting 24 AM. JUR. Game E Game Laws 382, §10); see Southview Assoc., Ltd. v. Bongartz, 980 F.2d 84 (2d Cir. 1992) (rejecting takings claim where developer barred from building on winter deer yard); Sierra Club v. Department of Forestry \& Fire Protection, 26 Cal. Rptr. 2d 338 (Cal. Ct. App. 1993) (rejecting takings challenge to California Forestry Board's denial of timber company proposal to cut 
These principles have also acted to prevent a private landowner from claiming a constitutional right to compensation for damage done to private property by wild animals, ${ }^{168}$ and insulated states from takings claims brought by fishers against state regulations. ${ }^{169}$

trees on private land absent satisfactory plan to mitigate adverse impacts on endangered species); Flotilla Game \& Freshwater Fish Comm'n v. Flotilla, 636 So. 2d 761 (Fla. Dist. Ct. App. 1994) (rejecting takings challenge arising from prohibition against land development within 750 feet of nesting bald eagles); Bauer v. Game, Forestation \& Parks Comm'n, 293 N.W. 282 (Neb. 1940) (holding that owner of land within designated game refuge area not deprived of property right by prohibition against hunting on own property); Schwartzman v. Berle, 415 N.Y.S.2d 187, 189 (N.Y. 1979) (rejecting challenge to New. York Department of Environmental Conservation's denial of an application for a hunting permit, observing that "[p]reservation of fish and game is a matter vithin public interest since, without adequate and special protect, they would be wasted and destroyed"); Barrett v. State, 116 N.E. 99, 100 (N.Y. 1917) (holding no infringement of private property rights when the State prohibited landowners from molesting wild beaver which had destroyed a private stand of valuable trees, and saying "Ownership of [wild animals] is in the state in its sovereign capacity, for the benefit of all people. Their preservation is a matter of public interest. They' are a species of natural wealth that without special protection would be destroyed. Everywhere and at all times governments have assumed the right to prescribe how and when they may be taken or killed.).

168. See Maitland v. People, 23 P.2d 116, 117 (Colo. 1933) (refusing to find an infringement where government protected wild deer-damaged crops, reasoning that "whenever legislative protection is accorded game, some harm usually is done to some person as an incident to such protection," but "such incidental injuries are not sufficient to render the protecting statute unconstitutional"); Moerman v. State, 21 Cal. Rptr. 329 (Cal. Ct. App. 1993) (holding state not liable for reintroduced Tule elk, which destroyed landowner's fences and ate forage intended for livestock); Leger v. Louisiana Dep't of Wildlife \& Fisheries, 306 So. 2d 391 (La. C.. App. 1975) (holding that because wildlife is regulated by states in their sovereign capacity, a state has no duty to control the movement of wildlife or to prevent it from damaging property); Massar v. New York State Thruway Auth., 228 N.Y.S.2d 777, 779 (N.Y. Ct. Cl. 1962) (rejecting claim for damages when motorist hit a wild deer, and stating that " $[t]$ he government has the right to protect wild animals for the benefit of the public at large and no one has the right to complain of incidental injuries which may occur as a result"); see also Christy v. Hodel, 857 F.2d 1324 (9th Cir. 1988) (rejecting challenge to Endangered Species Act regulations prohibiting the killing of grizzly bear ); Mountain States Legal Found. v. Hodel, 799 F.2d 1423 (10th Cir. 1986) (rejecting request for compensation where federally managed wild horses and burros caused extensive damage to private grazing lands). Doremus characterizes the Ninth Circuit's decision in Christy as equating losses of livestock due to wildlife predation with losses due to fire, floods, or other natural disasters, and agrees with the court's holding that the government need not insure landowners against such losses. Doremus, supra note 36, at 47.

169. Burns Harbor Fish Co. v. Ralston, 800 F. Supp. 722 (S.D. Ind. 1992) (holding that gill net ban does not constitute unconstitutional taking of fisher's property interests); Organized Fishermen v. Watt, 590 F. Supp. 805 (S.D. Fla. 1984) (holding that regulations restricting fishing in Everglades are not an unconstitutional taking of licensed fishers' property); LaBauve v. Louisiana Wildlife \& Fisheries Comm'n, 444 F. Supp. 1370 (E.D. La. 1978) (" $[\mathrm{F}]$ ish which are at large in state waters are the property of the state, as public or common things."); see generally Britton, supra note 163 , at 236 ("Essentially, fishermen have been regarded . . a as possessing no compensable, or prosecutable, property' interests for purposes of the Fifth 
Pre-Hughes cases retain precedential vitality precisely because the Court left intact the State's underlying, preeminent fiduciary duty to protect wildlife on behalf of its citizens. This duty is reflective of the Crown's prerogatives over wildlife and of common law principles which held that living wildlife cannot be reduced to private ownership, but must remain under the control of the sovereign to protect and maintain for the citizens of the realm. The continued vitality of this state duty and supportive common law maxims would appear to make them background principles of state common law that arguably inhere in title to property ${ }^{170}$ and restrict the freedom of landowners to take any action in derogation of state wildlife resources. State laws reflecting these concepts merely reify those common law principles. ${ }^{171}$

\section{B. THE PUBLIC TRUST DOCTRINE}

These same protective state wildlife laws also reify a complementary common law principle known as the public trust doctrine, under which the State acts as a trustee for the public's dominant ownership interest in certain types of lands, including lands that are privately owned. State courts today rely on the public trust doctrine to protect lands invested with the trust from conversion to uses that are not deemed to be in the public interest. The public trust doctrine, therefore, could provide a separate basis for

Amendment, which is a natural consequence of the history of the common property resources as established in history and under the common law."). Exclusive pre-capture, tradable property rights in wildlife and fish began to emerge at the close of the twentieth century as an alternative non-regulatory means of managing the taking of species that are severely depleted. See Alison Rieser, Property Rights and Ecosystem Management in U.S. Fisheries: Contracting for the Commons?, 24 ECOLOGY L.Q. 813, 826-27 (1997) ("[W]hen a community holds the rights to a resource, it can in turn subdivide those rights and allocate them among members of the community in a variety of complex and highly nuanced ways, reflecting peculiar aspects of the resource and its environment."); see generally THE QUESTION OF "THE COMMONS, supra note 70 (presenting case studies of management and use of fisheries resources from a the perspective of the "commons").

170. See Lucas v. South Carolina Coastal Council, 505 U.S. 1003, 1029 (1992) (emphasis added) (stating that severe limitations on economic use of land cannot be newly legislated or decreed).

171. The discussion of state prerogatives over wildlife and wildlife habitat is not meant to imply that states have exclusive control over wildlife; rather, state authority over wildlife is shared concurrently with the federal government. Thus, the federal government regulates the taking of endangered species, manages wildlife on federal land, conducts animal damage control programs, enforces international treaties and environmental legislation relating to wildlife, regulates commerce in wildlife, and operates wildlife research programs. Although the federal role in wildlife management has expanded significantly because of its constitutional foundation, state control of wildlife still predominates. An obvious question, but one which is beyond the scope of this Article, is whether the Lucas exception for background principles of common law applies to federal as well as state wildlife laws. • 
contending that state laws protecting wildlife habitat, as opposed to those protecting the animals themselves, inhere in private title to property.

The public trust doctrine is an ancient ${ }^{172}$ and, until recently, ${ }^{173}$ relatively obscure common law doctrine, under which the King of England held lands subject to the ebb and flow of the tides in trust for his subjects. ${ }^{174}$ The sovereign could not alienate these lands in favor of a private individual. ${ }^{175}$ The doctrine crossed the ocean, and when the colonies achieved independence from the Crown, submerged tidelands (and other types of water-based wildlife habitat) became vested in the several states ${ }^{176}$ and impressed with a

172. Helmholz cites several sources for the principle that rivers are "public," and that legal actions could be brought since Roman times for the removal of obstacles standing in the way of "the convenience of navigation." Helmholz, supra note 133, at 356.

173. Most public trust scholars credit Sax's seminal 1970 article for awakening a dormant doctrine that had slept for at least a century in this country. Joseph L. Sax, The Public Trust Doctrine in Nalural Resource Law: Effective Julicial Intervention, 68 MICH. L. REv. 471 (1970) [hereinafter Sax, The Public Trust Doctrine]. Without detracting from the significance of Sax's contribution, see MOlly Selvin, This TENDER and Delicate BuSINESS: THE PUBlic TRUST DOCTRINE IN AMERICAN LAW AND ECONOMIC POLICY 1789-1920 (1987) (demonstrating that the public trust doctrine retained vitality during the nineteenth and early twentieth centuries).

174. For a complete analysis and discussion of the history and legal parameters of the public trust doctrine, see generally Sax, The Public Trust Doctrine, supra note 173. On the specific topic of the effect of the public trust doctrine on takings challenges to regulations protecting wetlands and coastal barrier beaches, see Babcock, The Impact of Lucas, supra note 14. On the use of the public trust doctrine as a way to prevent the anti-commons from occurring, and to prevent hidden costs from being imposed on society by the one-way "ratchet of fragmentation," see Heller, supra note 12, at 1210 n.220.

175. Rasband takes issue with this historical account of the public trust doctrine, saying it is based on two fictions. James R. Rasband, Equitable Compensation for Public Trust Takings, $69 \mathrm{U}$. CoLO. L. REv. 331, 364-66 (1998). The first is that the King could not alienate lands under navigable water, which he finds to be only partially true. Id. According to Rasband, the King was only presumed to hold these lands in trust for the people and could defeat the presumption by a clear and unequivocal grant. Id. Indeed, the King conveyed almost all of this land as well as numerous fisheries to private individuals. Id. The only limitation on the King's powers was that it could not deny the public right of navigation. Id. The second fiction, according to Rasband, is ignoring that the colonies inherited the power of Parliament as well, and that there was never any question about Parliament, as the representative of the people, having the power to not only to convey land under navigable waters, but also to extinguish any public right of passage. Id.

176. New states admitted to the Union gained title to submergred lands under the Equal Footing Doctrine, which guarantees to new states governmental authority equal to that possessed by states already admitted. See Pollard v. Hagen, 44 U.S. (3 How.) 212, 229 (1845) (holding that title to lands underlying navigable waters passed to the states, not to the federal government); see also Coyle v. Smith, 221 U.S. 559, 566-67 (1911) (holding that the Equal Footing Doctrine ensures that newly admitted states will possess governmenzal authority equal to all other states). As noted in the text, title to these submerged lands was impressed with the public trust doctrine. 


\section{"like trust" on behalf of their citizens. ${ }^{177}$}

Courts have used the public trust doctrine to protect public use rights in trust lands and to restrict government (and private) actions that alienate or otherwise adversely affect those rights. Some courts have interpreted the doctrine as imposing an affirmative obligation on states to preserve trust resources for the benefit of the public, ${ }^{178}$ although this application of the doctrine remains even more controversial than the doctrine itself. ${ }^{179}$ Initially applied to protect public rights of fishing, oystering, fowling, and navigation, state courts have extended the doctrine's geographic reach from wet to fast (or dry) lands, and have expanded its scope to protect recreational, educational, scientific, and aesthetic uses of trust property. ${ }^{180}$

177. See Phillips Petroleum Co. v. Mississippi, 484 U.S. 469, 473 (1988) (recognizing the "like trust"); Shively v. Bowlby, 152 U.S. 1, 57 (1893) ("Upon the settlement of the Colonies, like rights passed to the grantees in the royal charters, in trust for the communities to be established."); Arnold v. Mundy, 6 N.J.L. 1, $69-73$ (N.J. 1821) (presenting the idea of a "like trust" by holding that common property (property that belongs to all the citizens, including air, water, sea, fish, and wild beasts) cannot be vested in all the people; therefore "the wisdom of the law has placed it in the hands of the sovereign power to be held, protected, and regulated for the common use and benefit").

178. See State v. Jersey Cent. Power \& Light Co., 351 A.2d 337 (N.J. 1976) ("The State has not only the right, but also the affirmative fiduciary obligation to ensure that the rights of the public to a viable marine environment are protected and to seek compensation for any diminution in that trust corpus."); see also In re Steuart Transp. Co., 495 F. Supp. 38, 40 (E.D. Va. 1980) ("Under the public trust doctrine, the State ... and the United States have the right and the duty to protect and preserve the public's interest in natural wildlife resources. Such right does not derive from the ownership of the resources but from a duty owing to the people.").

179. See infra note 190 (listing some of the authors who have written articles critical of the public trust doctrine). This Article does not purport to venture into the treacherous waters of defending or decrying the public trust doctrine, and discusses it here only for the purpose of identifying another source of common law that is protective of wildlife habitat.

180. See generally Scott W. Reed, The Public Trust Doctrine: Is it Amphibious?, I ENVTL. L. \& LIT. 107 (1986) (recounting the steady accretion of the public trust doctrine); see Marks v. Whitney, 491 P.2d 374, 380 (Cal. 1972). The court noted that:

There is a growing public recognition that one of the most important public uses of the tidelands-a use encompassed within the tidelands trust-is the preservation of those lands in their natural state, so that they may serve as ecological units for scientific study, as open space, and as environments which provide food and habitat for birds and marine life, and which favorably affect the scenery and climate of the area.

Id. at 380; see National Audubon Soc'y v. Superior Court, 658 P.2d 709 (Cal. 1983) (applying public trust doctrine to prevent Los Angeles from draining non-tidal tributaries flowing into navigable lake); Just v. Marinette County, 201 N.W.2d 761 (Wis. 1972) (applying the public trust doctrine to wetlands). States have also used the public trust doctrine to recover damages for injuries to natural resources, including fish and wildlife. See State v. Jersey Cent. Power \&e Light Co., 308 A.2d 671, 674 (N.J. Super. Ct. Law Div. 1973) (noting the diminishment to the public trust by the loss of fish stemming from actions by the power company). 
National Audubon Society v. Superior Court of Alpine County ${ }^{181}$ remains the most celebrated modern application of the doctrine, ${ }^{182}$ where it was used to prevent Los Angeles from draining streams that fed an interior lake of substantial wildlife importance. ${ }^{183}$ Since property containing trust lands is conveyed subject to the doctrine, ${ }^{184}$ absolute private dominion over property impressed with the public trust can never be granted unless it is in the public interest to do so. ${ }^{185}$

The State can no more abdicate its trust over property in which the whole people are interested, like navigable waters and soils under them, so as to leave them entirely under the use and control of private parties ... than it can abdicate its police powers in the administration of government and the preservation of the peace. ${ }^{186}$

Uses of trust property inconsistent with the public trust doctrine are revocable, and the power of the State to revoke those uses can never be lost, except by specific act of the state legislature. ${ }^{187}$

Because the sovereign cannot alienate trust property in favor of private interests, nor can private property owners do anything in derogation of the trust, private property rights are subordinate to the dominant public

181. 658 P.2d 709 (Cal. 1983).

182. A recent search on Lexis returned over two hundred law journal articles discussing National Audubon Society's impact on state applications of the public trust doctrine.

183. National Audubon Soc'y, 658 P.2d at 711-12, 727.

184. Shively v. Bowlby, 152 U.S. 1, 49-50 (1894) (holding that navigable waters and the underlying land are held in trust by the United States for the people because their chief benefit is for public purposes such as navigation and commerce, and "[they] shall not be disposed of piecemeal to individuals, as private property but shall be held as a whole for the purpose of being ultimately administered and dealt with for the public benefit by the state ...").

185. See National Audubon Soc'y, 658 P.2d at 723 ('Except for those rare instances in which a grantee may acquire a right to use former trust property free of trust restriction the grantee holds subject to the trust ... he can claim no vested right to bar recognition of the trust or state action to carry out its purposes.").

186. Illinois Cent. R.R. v. Illinois, 146 U.S. 387,453 (1892). Rasband is particularly perturbed by how courts and legal scholars have misused Illinois Central, and exposes what he believes to be the inconsistencies and weaknesses in Justice Field's reasoning. Rasband, supra note 175, at 344-80. He further warns scholars, who seek to expand the reach of the public trust doctrine, not to rely on Illinois Central for support, and not to compound the error by failing to heed the whole message of the case-where the public trust doctrine is employed, it necessarily includes equitable compensation for the grantee. Id. at 334 .

187. Illinois Cent., 146 U.S. at 455. Rasband contends that one of the unresolved questions from Illinois Central is whether a grant of trust resources is voidable or void $a b$ initio, noting there is language in the opinion suggestive of both readings. Rasband, supra note 175 , at 35859. 
interest in those lands. ${ }^{188}$ Any conveyance of private property containing trust resources, therefore, is subject to overriding public rights in that property. ${ }^{189}$ The State has the equivalent of an easement over trust lands that permanently burdens their ownership in favor of the general public, making the owner of those lands little more than a custodian of trust resources for present and future generations to the extent of the public trust rights. One cannot construct a common law canon more offensive to the notion of absolute private rights in property than the public trust doctrine. ${ }^{190}$

Because doctrinally, the right to convert a trust resource to private use

188. Another way of looking at how the public trust doctrine displaces private rights in land is to examine the question from a temporal perspective. Public trust rights attach to the land from the moment the sovereign claims title to the lands in question. Since private rights in these lands must per force attach later than the public's rights, the landowner's title cannot contain any public rights, unless specifically conveyed by act of the legislature.

189. The decision of the California Supreme Court in National Audubon Society was the first recognition by a court of the inconsistency of the prior appropriation doctrine and the public trust doctrine. National Audubon Soc'y, 658 P.2d at 712. For an expansion on these ideas of inconsistency within the legal regime governing water use, see Freyfogle, Oumership, supra note 31 , at 179-80 (criticizing the transformation of the original riparian doctrine, which prevented a landowner from altering in any way the natural flow of the stream, into a new doctrine which some alteration of the stream's flow under a principle of reasonable use).

190. One can easily see why the doctrine is extremely controversial and has drawn the criticism of several prominent legal scholars. See, e.g., William D. Araiza, Democracy, Distrust, and the Public Trust: Pracess Based Constitutional Theory, the Public Trust Doctrine, and the Search for a Substantive Environmental Value, 45 UCLA L. REV, 385 (1997) (arguing that the judicial scrutiny given to the public trust doctrine is misplaced because decision making about resource allocation requires technical decisions about competing goals, and is best left to the states with the courts reviewing only to ensure that the government implemented the programs decided upon by the people of the state); James L. Huffman, A Fish Out of Water: The Public Trust Doctrine in a Constitutional Democracy, 19 ENVTL. L. 527 (1989) (concluding that the public trust doctrine is best understood and treated as part of property law, and that the modern public trust case law cannot be justified because it is incompatible with both property law and values of a constitutional democracy); Richard Lazarus, Changing Concepts of Property and Sovereignty in Natural Resources: Questioning the Public Trust Doctrine, 71 lowa L. REv. 631 (1986) (criticizing the public trust doctrine as increasing the difficulty in reworking natural resources law, and contributing to the tension in the liberal ideology between individual rights, as represented by private property protection, and long-term collective goals, represented by government programs that protect the environment); Rasband, supra note 175 (criticizing the public trust doctrine as being based on fiction because the King could alienate lands under navigable waters with a clear and unequivocal grant, and that the colonies assumed the powers of Parliament to take away public rights of passage). One of the most troubling criticisms of the doctrine is that it is anti-democratic or counter-majoritarian because it allows politically unaccountable judges to make resource allocation decisions that should be made by the representative branches of government. Indeed, scholars have searched for ways to limit unrestricted judicial review of otherwise legitimate governmental action under the public trust doctrine. See Araiza, supra, at 438-51 (suggesting that state constitutional provisions dealing with the environment provide substantive support for and give effect to the will of the polity that government accord a higher value to public trust conservation). 
is not included in title to private lands, or is a right which the State can defease at any time, ${ }^{191}$ any restriction on private use of trust resources cannot constitute a taking of private property. ${ }^{192}$ To allow a landowner to displace the dominant public interest by a takings claim would be the equivalent of saying the State cannot protect its interest in those lands. ${ }^{193}$ Indeed, courts have held that state land use restrictions were not takings when the restricted uses were inconsistent with the public trust. ${ }^{194}$ Thus, under the Court's reasoning in Lucas, if lands inhabited by wildlife fall within the reach of the common law public trust doctrine, the doctrine would appear to insulate from takings claims state laws protecting such land. ${ }^{195}$

191. The concept that the State holds a reversionary interest in trust property is merely reflective of the fact that some forms of property cannot be owned by or belong to a single individual. Leif Wenar, The Concept of Property and the Takings Clause, 97 COLUM. L. REv. 1923, 1943-45 (1997).

192. See Callopy v. Wildlife Comm'n Dep't Natural Resources, 625 P.2d 994, 1000 (Colo. 1981) (holding that because the right to hunt game on one's land is not a "property" right, the closure of hunting in a region in which the land is located cannot constitute a taking for which compensation is required). On the topic of hunting and the public trust in general, see Darren K. Cottriel, Comment, The Right to Hunt in the Tuenty-First Century: Can the Public Trust Doctrine Save an American Tradition?, 27 PAC. LJ. 1235 (1996) (citing the public trust doctrine as a source of the modern right to hunt).

193. See Orion Corp. v. State, 747 P.2d 1062, 1072 (Wash. 1987) (holding that the public trust doctrine precluded takings claim because ticle to trust resources was acquired subject to whatever state action was necessary to protect public's interest in trust resources); see also Kleppe v. New Mexico, 426 U.S. 529 (1976) (finding the federal government's power under the Property Clause of the Constitution, Art. IV, § 3, cl. 2, is without limitation); Pollard v. Hagen, 44 U.S. (3 How.) 212, 222 (1845) (giving the several states comparable powers over tidelands).

194. See, e.g., Marks v. Whitney, 6 Cal. 3d 251, 260-61 (Cal. 1971) (holding restrictions on filling tidelands not a taking because the restricted landowner held tidelands subject to the public trust); Coastal Petroleum v. Chiles, 701 So. 2d 619 (Fla. 1997) (holding state statutory prohibition on oil exploration and drilling in areas where oil company has a royalty interest under a settlement agreement with the State was not a taking based in part on state's affirmative public trust obligation to restrict or eliminate private activity on sovereign lands that is contrary to the public interest); National Assoc. of Home Builders v. New' Jersey Dep't of Envtl. Protection, 64 F. Supp. 2d 354 (N.J. 1999) (holding that the requirement that developers construct a public access walkway on their waterfront property was not a taking, because under the public trust doctrine the State holds in trust the citizens' right to waterfront access, and therefore the developers did not have a right to exclude the public from the property in the first place).

195. Rasband argues strenuously against the wisdom of pursuing a course that denies any compensation for grantees whose property is taken by a public trust easement. Rasband, supra note 175 , at 405 . He suggests instead that the principle of equitable compensation for improvements made by private property owners to lands impressed with a public trust should be engrafted into the doctrine. Id. Such an approach, according to Rasband, might unite both the detractors and supporters of the doctrine because for the detractors, the doctrine will seem more fair, and for the supporters, compensation for improvements is a small price to pay for 
There can be no question that traditional trust property of vital importance to many species of wildlife, like tidelands, ${ }^{196}$ falls within the protective reach of the public trust doctrine.

The fish within our waters, constitute the most important constituent of that species of property commonly designated as wild game, the general right and ownership of which is in the people of the State [citation] as in England it was the king; and the right and power to protect and preserve such property for the common use and benefit is one of the recognized prerogatives of the sovereign, coming to us from the common law .... The complaint shows that, by the repeated and continuing acts of defendant, this public property right is being, and will continue to be, greatly interfered with and impaired; and that such acts constitute a nuisance.... ${ }^{197}$

There are other lands of great importance to non-water dependent species, however, that do not so obviously fall within the doctrine's reach. But just as the scope of the doctrine has been expanded to cover lands and activities that were not traditionally reached by it, one could argue in favor of further expansion to protect non-water based wildlife habitat, such as forests or prairies, because of the communal services these lands perform.

Carol Rose explains that "property in which the whole people are interested" ${ }^{\prime 198}$ has been historically protected by the public trust doctrine from "contradictory individualized claims of right"199 because it performs important communal and educative functions. ${ }^{200}$ She labels such lands "inherently public lands" and the services they perform "doux commerce."201

the improvident natural resource grants of the past. Id.

196. See People v. Truckee Lumber Co., 48 P. 374 (Cal. 1897) (issuing injunction barring continued operation of private sawmill that polluted Truckee River).

197. Id. at 374 (citations omitted), quoted in Andrew H. Sawyer, Changing Landscapes and Evolving Law: Lessons from Mono Lake on Takings and the Public Trust, 50 OKLA. L. REV. 311, 332-33 (1997); see California Trout, Inc. v. State Water Resources Control Bd., 255 Cal. Rptr. 184, 209, 212 (Cal. Ct. App. 1989) (stating that the Fish \& Game Code provisions requiring passage of water to keep fish in good condition downstream of dams are a legislative expression of the public trust).

198. Illinois Cent. R.R. v. Illinois, 146 U.S. 387, 453 (1892).

199. Gordon, supra note 16 , at 97 . Gordon goes on to note that these public rights were presented as inroads upon or qualifications of a presumed set of individual property rights or more often were conceptualized as something the proprietor had never "owned,' or fully owned to begin with." Id.

200. See generally Rose, The Comedy of the Commons, supra note 70 (discussing the necessities of protecting land in which the public is interested).

201. Id. at 775. Rose has identified commerce as the central object of early inherently public property doctrines (such as public trust and custom). Id. at 774. "Inherently public 
Lands which, regardless of their traditional public trust characteristics, sustain wildlife, provide a wide range of what Barton Thompson calls "ecosystem services" of "inestimable value to the human race."202 Wildlife is res communes; its highest value is as a communal (or public) resource. Recognizing wildlife's public value, courts since $\mathrm{Geer}^{203}$ have impressed upon wildlife a trust for reasons that resonate with scholars, like Rose and Thompson, who have made much of property's communal features. ${ }^{204}$ States that consider wildlife to be covered by the public trust doctrine, ${ }^{205}$ and those that still claim ownership of resident fish and wildlife, do so because of the important communal values of those resources. ${ }^{206}$ Laws pro-

property," the object of those ancient doctrines, held out the possibility of infinite "returns to scale," id. at 761-71, making the property extremely valuable to eighteenth- and nineteenthcentury England. Id. at 766-74. But returns to scale, or the capacity to expand wealth, was not the only feature of commerce in that era. According to Rose, commerce had educative and socializing virtues as well. Id. at $\mathbf{7 7 5}$. The twentieth-century equivalent of "doux commerce," Rose writes, is recreation. Lands devoted to recreational uses achieve the highest value when preserved for the public at large. Id. at 779-80.

202. Barton H. Thompson, Jr., People or Prairie Chickens: The Uncerlain Search for Optimal Biodiversity, 51 STAN. L. REv. 1127, 1137 (1999). Thompson lists other sources of economic value attributable to endangered species, such as its direct harvest value, its value from tourism, its pharmaceutical, medicinal, industrial and agricultural uses, and its hedonic value (public's willingness to pay). Id. at 1133-35. Although Thompson's article focuses exclusively on endangered species, comparable values can be assigned to non-endangered wildlife. See supra note 35 (discussing instances in which considerable value is placed on non-endangered wildlife).

203. 161 U.S. 519 (1896).

204. Applying Rose's formula, wildlife has its highest value when it is preserved for the public at large, cannot be reduced to individual ownership unless captured, and has both important commercial and socializing (or recreational and educational) value. Rose, The Comedy of the Commons, supra note 70, at 711-12. In addition to these largely utilizarian arguments for wildlife protection that stress the practical importance of wildlife to the human community, there are also ethical arguments, referred to as the "Noah Principle," which emphasize the intrinsic importance of each species and humankind's moral duty not to cause the extinction of any one. Paula C. Murray, Private Takings of Endangered Species as Public Nuisance: Lucas v. South Carolina Coastal Council and the Endangered Species Act, 12 ENVTL. L.J. 119, 162-63 (1993).

205. See, e.g., California Trout, Inc. v. State Water Resources Control Bd., 255 Cal. Rptr. 184, 198 (Cal. Ct. App. 1989) (applying public trust doctrine to wild trout, and stating that wild fish have always been recognized as a species of property and the general right and ownership of the fish is in the people of the State); Wade v. Kramer, 459 N.E.2d 1025, 1027 (IIl. App. C. 1984) (balancing public interest in wildlife against public benefit of a highway in accordance with the public trust doctrine, and concluding that highway benefits justify detriment to wildlife); see In re Steuart Transp. Co., 495 F. Supp. 38, 39 (E.D. Va. 1980) (stating that based on public trust analysis, state and federal governments may bring claims against oil barge owner for harm done to waterfowl from oil leak).

206. Several states that claim title to or ownership of resident fish and wildlife base those claims on the wildlife's being a trust resource. See, e.g., AlASKa CONST. art. VIII, $\S 3$ (1999) 
tecting wild animals and the resources on which they depend affirm the State's connection to the community it serves, and reify socializing elements that have been stripped away from property law in this century by "the absolute dominion trope."207

The historical antecedents of modern property law in this country and of the laws protecting wildlife ${ }^{208}$ reveal that the use of private property has always been constrained by transcendent social or communal obligations, ${ }^{209}$ including the obligation to avoid harming wild animals and the lands upon which they depend. Laws protecting wildlife resources have historically been part of the preexisting common law of most states, and state courts, relying on the common law doctrines of state wildlife trust and public trust, have repeatedly sustained those laws in the face of assertions of contrary individual private rights. "To a layman, and even to a lawyer who has not had occasion to deal with the subject, the extent of the power of the states

(providing that wherever fish, wildlife and waters occur in their natural state, they are reserved to the people for common use); LA. CoNST. art. IX, $\S \S 1,7$ (1999) (requiring state to protect, 'conserve, and replenish all natural resources, including the wildlife and fish of the State, for the benefit of the people). Other states recognize the state wildlife trust doctrine in their statutes. See N.C. GEN. STAT. §§ 113-133.1 (1994) (providing that the enjoyment of the state's wildlife resources belongs to all of the people of the state); see generally Peter N. Davis, Protecting Waste Assimilation Stream Flows by the Law of Water Allocation, Nuisance, and Public Trust, and by Environmental Statutes, 28 NAT. RESOURCES J. 357, 378-79 nn.117-19 (1988); Babcock, The Impact of Lucas, supra note 14, at $41 \mathrm{n} .232$.

207. See generally Gordon, supra note 16 (arguing that the concept of "absolute dominion" has few real examples in history, where most property rights involved some fragmentation of the bundle of rights and collective management among owners, and that even rights characterized as "absolute" come in to conflict with rights of others, notably in the context of nuisance); Rose, supra note $\mathbf{5 0}$ (asserting that apart from the historical questions surrounding the accuracy of the theory of absolute property rights, the "linguistic trope of exclusivity" presents both practical and theoretical problems in modern times).

208. Although this Article focuses on state common law background principles, these same principles are also of relevance to federal wildlife restrictions. Since the Takings Clause, unlike the Commerce Clause and the Privileges and Immunities Clause of the U.S. Constitution, has been read to incorporate and rely upon state law in the context of a takings claim under the Fifth Amendment, the common law property doctrines discussed in this Article would govern the resolution of any constitutional claim arising from the application of a federal law. See Phillips v. Washington Legal Found., 524 U.S. 156, 164 (1998) (affirming that "the property interest is determined by reference to existing rules or understandings that stem from an independent source such as state law"). Therefore, even if the case involves a federal restriction, the nature of the property interest allegedly infringed, and the question whether background principles apply, will be decided as a matter of state law.

209. Epstein notes that the level of agreement among the states on what these background principles are is far greater than sometimes supposed, which he attributes to the existence of various Restatements and treatises. Epstein, supra note 22, at 41. Another reason identified by Epstein is the historicity of these understandings. See id. (arguing that historical differences are not so great as supposed). But see Humbach, Evolving Thresholds, supra note 14, at 773 (expressing concern that Lucas will result in scattered judicial applications of the Takings Clause). 
with reference to fish, game, and all wild life within their borders is perfectly astounding." ${ }^{210}$ State laws protecting wild animals and the lands that sustain them, therefore, reflect long-held background principles of common law, under which a state's authority to regulate and protect wildlife resources is seen as superior to any conflicting private right or interest in the land on which wildlife roams. ${ }^{11}$ These laws, therefore, are the paradigmatic example of laws that "inhere [themselves], in the restrictions that the background principles of the State's law of property and nuisance already place on land ownership." 212

\section{REIFIEd Communal VAlues}

The state wildlife trust and public trust doctrines offer common law axioms that reflect the sense of community essential to restoring an improved land ethic as part of private property ownership. ${ }^{213}$ Under these doctrines, a landowner simply cannot use her property in a way that harms the community by destroying wildlife or wildlife habitat and then demand compensation if ordered to stop. ${ }^{214}$ Folding those doctrines into our discourse about land ownership enriches that discussion by adding back into it a way of talking meaningfully about land uses that threaten the communal whole. ${ }^{215}$

Eric Freyfogle and Joseph Sax find much to blame for the current ill health of our land in what they call this modern "spin" on the institution of private property-that property ownership "is a God-given construct, an

210. Cook v. State, 74 P.2d 199, 201 (Wash. 1937).

211. Although beyond the scope of this Article's focus on background principles of property law, it is also worth pointing out that laws protecting wildlife and wildlife habitat also fit within a state's common law parens patriae authority to abate nuisances which injure the public health and comfort. The parens patriae doctrine has long applied to the protection of natural resources, authorizing states to seek injunctive relief for a collective injury to a substantial number of its citizens where no private individual has standing to proceed. See, e.g., North Dakota v. Minnesota, 263 U.S. 365 (1923) (flooding caused by change in drainage system); New York v. New Jersey, 256 U.S. 296 (1921) (discharge of sewage); Georgia v. Tennessee Copper, 206 U.S. 230 (1907) (air pollution); Missouri v. Illinois, 180 U.S. 208 (1901) (discharge of sewage).

212. Lucas v. South Carolina Coastal Council, 505 U.S. 1003, 1029 (1992) (emphasis added).

213. According to Freyfogle, viewing property as a communal resource additionally creates an opportunity to harmonize the notion of private rights in property with an ecologically sound land ethic. Freyfogle, Ethics, supra note 54, at 632.

214. Freyfogle, Oumership, supra note 31 , at 184 .

215. Freyfogle, Ethics, supra note 54 , at 645 . Freyfogle does not advocate the abolition of private ownership, rather he wants to see ownership norms infused with a land ethic based on the durable wisdom of ecology so that private ownership is seen as entailing responsibility, of belonging to a community, and abiding by its norms. Id. at 661 . 
idea etched in unchangeable stone or inked on some unassailable parchment" ${ }^{216}$-because this myth has suppressed more propitious communal property norms. ${ }^{217}$ The myth has prevented landowners from developing an ecologically sound land ethic ${ }^{218}$ and fostered a loss of capacity to be good neighbors. ${ }^{219}$ It has led to the uncoupling of government from the community, making it easier to view the government not as the community's agent, but as an entity that exists independent of the people, with interests distinct from the common good. ${ }^{220}$

216. Freyfogle, Oumership, supra note 31 , at 178 ("Like many cultural artifacts, the institution of private land ownership today is weighted down by contradictions.") (citing Sax, Property Rights, supra note 14). Unfortunately, it does not appear that this absolutist image will disappear anytime soon. The vision of an "owner" in undisturbed enjoyment of her physical things "offers something to everyone-security, autonomy, expressive freedom, protection from arbitrary encroachment or restraint, participation as an equal in economic and civic hife." Gordon, supra note 16 , at 108.

217. Gordon contends that the suppression of communal property norms, what he calls "the collective and collaborative elements of society arising from the necessity of mutual dependence," has suppressed our common capacities to understand and regulate our social life. Id.

218. See generally Freyfogle, Ethics, supra note 54, at 646-50 (discussing how current private property norms prevent landowners from developing an ecologically sound land ethic).

219. Rose, Canons of Property Talk, supra note 50, at 632. Another factor that may mitigate against thinking more communally and behaving in a more ecologically sensitive way is a phenomenon called the endowment effect (our tendency to place a higher value on a possession than on something we do not possess). In an article examining the endowment effects of property, Rachlinski and Jourden conclude that equitable (or property) rules may more accurately reflect how people feel about their possessions and rights than liability rules (damages). Jeffrey J. Rachlinski \& Forest Jourden, Remedies and the Psychology of Ownership, 51 VAND. L. REV. 1541, 1575 (1998). Their conclusion could have implications not only for the use of liability rules, as opposed to property rules, to make landowners who have suffered a taking feel whole, but may also explain why environmental advocates are so unwilling to accept compensation for losses of what they perceive to be an endowed property interest in wildlife. Rachlinski and Jourden warn that while the law has the ability to reduce the endowment effect by favoring damage remedies over injunctive relief, thereby facilitating Coasean bargains or trades, courts should be wary of "tinkering" with that remedy lest they run afoul of very real feelings that property owners have about their possessions. Id. at 1576. For more on the endowment effect, see generally Rose, supra note 50, at 618 (discussing how the endowment effect does not cure the "Ownership Anxiety," that somehow title rests on some essential flaw); and Stake, supra note $\mathbf{2 5}$, at 39 (discussing the application of the endowment effect to adverse possession).

220. See Freyfogle, Oumership, supra note 31, at 184 (characterizing the government both as an agent independent of the people and an agent to be exploited by the people); see also Torres, supra note 33 , at 5 (criticizing property rights advocates for their "willful ignorance of the social function of property: to bind us together as a society and culture, as well as to provide the basis for the maximal individual exclusion of others"). Mensch strikes a similar note when she observes a wedge being driven between individuals, whom she collectively refers to as private (or civil) society, and the government during the process of creating an abstract property right in colonial New York. Mensch, supra note 59, at 735. 
But this Article has shown that when privately owned land emerged as an abstract legal construct, it did not disturb either long-held notions of interpersonal relationships or communal duties that ran with the land and encumbered its use, such as a landowner's obligation to preserve wildlife. These communal strands of property are reflected in the state wildlife trust and public trust doctrines. The contradictory notion of absolute, individual rights in land without corresponding communal obligations is very new; its present-day vitality is largely a matter of uncontradicted political rhetoric in the last quarter of the twentieth century. ${ }^{221}$ The continued vitality of these common law doctrines demonstrates that the notion of absolute dominion has not completely suppressed property's more propitious communal norms. ${ }^{222}$

The state wildlife trust and public trust doctrines offer an antidote to our culture's loss of a sense of community and to our modern inability to see our society as individuals arrayed in a series of continuous interactions with each other and with our surroundings. ${ }^{223}$ Reification of property's communal norms in state wildlife laws, therefore, offers a way of combating what Carol Rose calls doctrinal "rights talk,"224 such as that found in notions of absolute private property ownership. ${ }^{25}$ Such talk, unchecked, even in the form of political bombast, ${ }^{226}$ can erect a subtle intellectual barrier to

221. See Echeverria, supra note 37, at 351-75 (discussing the apparent causes and contradictions of the emergence of property rights as a modern political phenomenon).

222. Eric Freyfogle, The Particulars of Ouning, 25 ECOLOCY L.Q. 574, 577-78 (1999). Freyfogle singles out as examples of durable core ownership norms, the right to exclude, liberal individualism, economic growth, and anthropocentric morality, but finds all but the first value slowly changing. Id. at $\mathbf{5 7 8}$.

223. Freyfogle, Ounership, supra note 31, at 184. A branch of complexity theory, evolutionary biology, espouses the same interconnectedness, recognizing that the "fitness landscapes of various species in the ecosystem are coupled by their temporal interactions, requiring that all species reconstruct their schemata and structures continually." Ruhl, supra note 33, at 1463. On the topic of loss of community, see MICHAEL J. SANDEL, DEMOCRACY'S DISCONTENT: AMERICA IN SEARCH OF a Public PhILOSOPHY (1996).

224. Rose fears that rights talk can run wild, sometimes with unfortunate results. Rose, Canons of Property Talk, supra note 50, at 617 (citing the example of radical, right wing common law courts being used to justify a revolutionary disregard of ordinary legal duties and neighborly behavior).

225. Carol Rose focuses on what she calls the Exclusivity Axiom, Blackstone's definition of property as exclusive dominion, in her critique of how property scholars have failed to explore the metaphoric quality of that definition, and notes that the axiom is a very forceful species of "rights-talk" because it symbolizes other rights, such as the exclusive right to one's own body. Id, at 623-30. This fact may explain why, for all its frailties, the Exclusivity Axiom continues to carry considerable weight even for those critical legal scholars who normally criticize bright line rules, because exclusivity can lead to the very kind of distributional and liberationist aims they propound. $I d$.

226. See Echeverria, supra note 37, at 362-65 (analyzing property rights as a political issue, 
understanding normal social practices like sharing and "neighborly giveand-take," where exclusivity gives way to the more fluid pattern of reciprocally giving favors and requesting help. ${ }^{227}$

While this Article does not advocate turning the clock back to an earlier time, it is useful to remind ourselves of the modern-day value of some of those earlier understandings about land tenure (ownership). If community is an essential component of the institution of property, then enforcing laws that embody common law communal norms, like wildlife protection, is one way of returning to a view of property in which landowners recognize their obligations toward society as a whole. The Court's decision in Lucas could be viewed as pointing us in that direction with its suggestion that the lower courts look to common law norms for guidance in determining what separates permissible from impermissible restrictions on property.

Therefore, Lucas, oddly enough, with its incorporation of the common law into takings jurisprudence, may allow us to regain that sense of neighborliness. However, that is possible only if the gap between the norms of absolute dominion and communal responsibility can be closed; otherwise, conflict and discord will continue. One way to close the gap might be to combine economic incentives for those landowners who are willing to enhance the communal values of private property with programs to reeducate the public about the importance of community and the role property can play in fostering communal values. ${ }^{228}$ Landowners might accept state intervention to achieve a communal goal more willingly if they understood the reasons for it, and received some reward for good (as opposed to punishment for bad) acts. Land restrictions that protect wildlife are a good place to begin this initiative because of the enduring strength of protective common law doctrines and because there are extant programs and mechanisms that might be employed. ${ }^{229}$

\section{CONCLUSION}

This Article has shown how "property" comprises an aggregate of so-

and examining the impact of the use of slogans, epithets, and sound bites in lieu of discussions of actual Supreme Court takings jurisprudence).

227. Rose, Canons of Property Talk, supra note 50, at 615; see Freyfogle, Oumership, supra note 31 , at 177 (deriding private property as an artificial, culturally created "mental abstraction" that should be changed because of its insensitive and destructive properties).

228. Innes endorses monetary incentives for landowners as a way of reducing the likelihood a property owner, sua sponte, might act to lessen the conservation value of her land by cutting down trees or surreptitiously killing protected species ("shoot, shovel, and shut up"). Innes et al., supra note 140 , at $44-45$.

229. Some examples might be tax or limited regulatory relief from the application of restrictive wildlife laws, financial incentives to offset lost value or increased cost from habitat enhancement measures, and public (or private) acquisition of conservation easements. 
cial and legal relationships made up of rights, privileges, powers, and immunities, ${ }^{23}$ which are defined and calibrated to fulfill important social functions beyond land's mere monetary value. ${ }^{231}$ The notion of land as a commodity valued only by its marketable produce has never been fully incorporated into the common law of property, nor has a view of ownership that requires land to be put to its most profitable use, exploited fully, and protected from public actions that diminish its value. ${ }^{232}$ Because of its important socializing functions, land ownership has been (and is still to this day) encumbered by the responsibility to use land within the bounds of community norms governing right and wrong land use. ${ }^{233}$ These norms require land to be treated properly and its owners to abide by local forms of propriety, ${ }^{234}$ and so promote the good order of the community. ${ }^{235}$ In eighteenth-century colonial America, property's communal purposes were most vividly realized in viewing privately held land as a commons, in which individuals could exercise shared use-rights like grazing, wood-gathering, hunting, and fishing, and which, in the extreme case, could be taken for some community purpose. ${ }^{236}$ Nuisance law, ${ }^{237}$ customary rules like those

230. Heller, supra note 12, at 1191 (citing Wesley Hohfield as the source of this thought); see Phillips v. Washington Legal Found., 524 U.S. 156, 164 (1998) (" $[$ P]roperty is more than economic value; it also consists of 'the group of rights which the so-called orner exercises in his dominion of the physical thing,' such 'as the right to possess, use and dispose of it."'), quoted in Heller, supra, at 1206 (citations omitted).

231. See Rose, The Comedy of the Commons, supra note 71, at 776-77 (finding educational and socializing functions in communal lands, which explains why inherently public property has been able to resist the classical economic presumption of exclusive orvnership control); see also Gregory S. Alexander, Takings and the Past-Modern Dialectic of Property, 9 CONST. COMMENTARY 259, 261 (Summer 1992) (describing property as an individual riglt that is in a dialectical relationship with the communitarian position that emphasizes the property owner's responsibility to the larger community); Torres, supra note 22, at 5 (criticizing property rights advocates for their ignorance of property's social functions).

232. Torres goes further, denouncing what he calls the "rhetoric of law and economics," which leads to "tunnel vision when it becomes prescriptive." Id.

233. Freyfogle finds a more modern application of this norm in western water law's maxim "use it beneficially or lose it." Freyfogle, Ethics, supra note 54, at 641 .

234. Id. at 638. Freyfogle notes that the cognates of "property" are "proper," "appropriate," and "propriety," and that in Locke's time "property" and "propriety" were viewed as synonyms. Id. at $639 \mathrm{n} .25$.

235. Id. (citing Carol M. Rose, Property as Wealh, Property as Propriety, in Nomos XXXIII: COMPENSATORY JUSTICE 223 (John W. Chapman ed., 1991)).

236. See supra Part III (discussing colonial land restrictions).

237. Freyfogle advocates the revitalization of public nuisance as a way to push landowners to act more responsibly toward their land because the doctrine draws upon communally set standards of right and wrong, and can be easily tailored to the peculiarities of a given place and thus help promote sensitivity to that place. Freyfogle, Ethics, supra note 54, at 656 . He sees public nuisance as a way of adding back into land ownership a way of talking meaningfully about land uses that threaten the communal whole, draving as it does from communally set 
governing the use of water, and "a few other corners of the law," such as the state wildlife trust and public trust doctrines, ${ }^{238}$ have perpetuated into the modern era the idea that land ownership entails communal constraints.

The conclusion that restrictive state laws fit within the common law exception to the Lucas per se takings rule, on the theory that they do no more than could have been achieved by the courts applying common law property principles, is nonetheless troubling. It is one thing to say that these principles reside comfortably in the common law, which they do, and even to see in their application a reification of important social values. It is quite another thing to say that they comport with what might be the average landowner's expectations about restraints on her title, which, in all likelihood, they may not.

This Article's interpretation of Lucas sets up an obvious conflict not only with what must be presumed to be the intent of the Court with regard to confiscatory regulations, but also with modern expectations about unencumbered, secure, and exclusive private property rights. ${ }^{239}$ The Lucas majority's assumption that landowner expectations would be aligned with common law principles, thus, may turn out to have been seriously flawed when applied to regulations protecting wildlife, not because the common law is too malleable, as Justice Blackmun decried, ${ }^{240}$ but because it admits of too much.

Those who care about protecting wildlife may find much to applaud in this Article's conclusion that wildlife laws may escape the Just Compensation Clause, thereby taking out of harm's way important wildlife habitat. So too, those who bemoan the loss of property's "doux commerce"241 and

standards of right and wrong. Id. Freyfogle also notes that when courts long ago applied nuisance law in actual cases, they drew on the community's sense of acceptable and unacceptable land use because it was the most sensible standard, as it best expressed the idea of law as the people's will. Eric T. Freyfogle, The Ouming and Taking of Sensitive Lands, 43 UCLA L. REV. 77, 123 (1995). Ellickson believes that there is considerable agreement on the identification of normal land uses. Robert C. Ellickson, Alternative to Zoning: Covenants, Nuisance Rules, and Fines as Land Use Controls, 40 U. CHI. L. REV. 681,729 (1973).

238. Additional "corners" are the common law doctrine of custom and aboriginal gathering rights. On the ancient doctrine of custom, see generally Rose, supra note 71, at 739-49; Babcock, The Impact of Lucas, supro note 14, at 30-35; and Stevens v. City of Cannon Beach, 854 P.2d 449, 456-57 (1993) (holding Oregon's customary public property rights in ocean beaches precluded a takings claim challenging regulations restricting private beach development). On native gathering rights, see Public Access Shoreline Haw. v. Hawaii County Planning Comm'n, 903 P.2d 1246 (Haw. 1995) (concluding that private rights in real estate held for development purposes are subject to native property rights).

239. See Echeverria, supra note 37, at 354-55 (explaining that powerful economic interests are using rights talk and hardship stories as part of an effort to weaken the federal ESA).

240. Lucas v. South Carolina Coastal Council, 505 U.S. 1003, 1032 n.18 (1992).

241. See generally Rose, The Comedy of the Commons, supra note 70, at 776-81 (discussing the 
other communal values may find comfort in a view of Lucas that reinserts traditional ethical and social norms into the notion of private, individualized property rights. But, no one should welcome continued conflict between landowner expectations and government actions, nor the ensuing legal challenges and legislative assaults on laws that protect wildlife invited by the decision's ambiguity. The fact that Lucas' promise of relief for landowners suffering confiscation of their property due to the application of some wildlife regulation may be little more than a chimera will keep wide and acute the wedge between private and public expectations about how land should be used, ${ }^{242}$ and may serve to exacerbate the sense of alienation and discontent among the citizenry toward actions taken by their government. ${ }^{243}$

There may be another troubling aspect of this exegesis of common law doctrines. Resting an outcome on an historical reading of property that finds outlet in musty common law doctrines could rightly be viewed as problematic in a much-changed world, even if the Lucas Court invited that result. ${ }^{244}$ Where regulation once stood in our public law "as an ordinary part of the background of risk and opportunity against which we all take our chances in our roles as investors in property," ${ }^{445}$ that no longer seems to be true in either the Court's or the public's mind. We have moved on from the era of feudum, villein, and the village commons. Property has

value of inherently common property in facilitating the expansion of commerce, and therefore increasing sociability, as people are forced to learn ways and practices of others in order to be successful).

242. See generally Mensch, supra note 59, at 734-35.

243. See generally SANDEL, supra note 223 (arguing that a shift in American politics from classic republicanism to liberalism has created a situation in which the freedom to opt out of involvement in the polis has created a situation in which the government is unable to provide solutions for the two major concerns facing Americans: the feeling that we are losing control over the forces that govern our lives, and that the moral fabric of oux communities is unraveling).

244. Rose criticizes Richard Epstein for lauding common law systems for their generation of categories of rights that are unchanging over time and fully specifiable. Rose, Canons of Property Talk, supra note 50, at 515.

245. Frank I. Michelman, The Common Law Baseline and Restitution for the Lost Commons: $A$ Reply to Professor Epstein, 64 U. CHI. L. REv. 57, 69 (1997). Wenar describes Michelman as having a "Rawlsian" reading of the Takings Clause, to the extent that he advocates that compensation for a redistribution of wealth is not required when a rational loser from such a redistribution could be expected to see that such decisions will benefit people like him in the long run. Wenar, supra note 191, at 1934 (citing Michelman, Property, Utility, and Faimess, supra note 11, at 1214-24). Indeed, some opponents of compensation suggest that insurance is the more feasible and efficient tool for protection against this risk and that the presence of compensation has prevented this market from developing. Lewinsohn-Zamir, supra note 11, at 66 n.57 (citing R.A. POSNER, ECONOMIC ANALYSIS OF LAW 50-1 (3d ed. 1986) and Louis Kaplow, An Economic Analysis of Legal Transitions, 99 HARV. L. REV. 511 (1986)). 
shown itself over time to be among the most malleable of social and legal constructs, best understood as a transitory embodiment of historically contingent conceptions that are prevalent in a particular culture at a specific point in time, not as some universal and immutable concept. ${ }^{246}$ As the meaning of property has metamorphosed, rights in land have been reconfigured to reflect shifting economic circumstances and changed social values. ${ }^{247}$ That absolute dominion over one's land may be seen as a "trope" when put into historical context is of little import if that concept has popular meaning today, which it appears to have.

Perhaps the Lucas Court did not solve the hard problem it set out to solve, the simplification of takings jurisprudence by converting a landowner's relative use right into an unassailable privilege. The decision's common law exception makes that privilege anything but unassailable. However, the Court may have done something more valuable, albeit unintended. By injecting common law communal norms into the crucible of takings jurisprudence, the Court has reminded us of "the necessity of mutual dependence inherent in any social endeavor, ${ }^{248}$ such as owning a portion of the natural landscape. It has further provided a normative framework for resolving property disputes, which may slow the rate at which public resources, like wildlife, may be freely privatized. At the same time, the Court has made it imperative that we reconcile the norm of neighborliness with that of absolute, exclusive dominion over land; if we succeed in that endeavor that will arguably be Lucas' most enduring legacy, and a golden opportunity will not have been lost.

246. Craig Rotherham, Conceptions of Property in Common Law Discourse, 18 LEGAL STUD. 41, 43 (1998); see id. at 44 (explaining that the history of rights in land shows that property is essentially a contested concept that changes over time to mirror the winners and losers in society). Rotherham also notes that the protection afforded to landowners has been based on norms derived not only from abstract conceptions of individual rights, but also from customs and notions of utility. Id. at 41 .

247. "The law is like clothing, which alters with the time." Rotherham, supra note 246, at 41 (citing Jones v. Powell (1629) Palm 536, 81 ER 1209 (1629)).

248. Gordon, supra note 16 , at 101. 


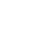

